IZA DP No. 10030

Immigration Enforcement and Childhood Poverty in the United States

Catalina Amuedo-Dorantes

Esther Arenas-Arroyo

Almudena Sevilla

June 2016 


\title{
Immigration Enforcement and Childhood Poverty in the United States
}

\author{
Catalina Amuedo-Dorantes \\ San Diego State University \\ and IZA \\ Esther Arenas-Arroyo \\ Queen Mary University of London \\ Almudena Sevilla \\ Queen Mary University of London \\ and IZA
}

\section{Discussion Paper No. 10030 \\ June 2016}

IZA
P.O. Box 7240
53072 Bonn
Germany

Phone: +49-228-3894-0

Fax: +49-228-3894-180

E-mail: iza@iza.org

\begin{abstract}
Any opinions expressed here are those of the author(s) and not those of IZA. Research published in this series may include views on policy, but the institute itself takes no institutional policy positions. The IZA research network is committed to the IZA Guiding Principles of Research Integrity.

The Institute for the Study of Labor (IZA) in Bonn is a local and virtual international research center and a place of communication between science, politics and business. IZA is an independent nonprofit organization supported by Deutsche Post Foundation. The center is associated with the University of Bonn and offers a stimulating research environment through its international network, workshops and conferences, data service, project support, research visits and doctoral program. IZA engages in (i) original and internationally competitive research in all fields of labor economics, (ii) development of policy concepts, and (iii) dissemination of research results and concepts to the interested public.
\end{abstract}

IZA Discussion Papers often represent preliminary work and are circulated to encourage discussion. Citation of such a paper should account for its provisional character. A revised version may be available directly from the author. 
IZA Discussion Paper No. 10030

June 2016

\section{ABSTRACT \\ Immigration Enforcement and Childhood Poverty in the United States}

Over the past two decades immigration enforcement has grown exponentially in the United States. We exploit the geographical and temporal variation in a novel index of the intensity of immigration enforcement between 2005 and 2011 to show how the average yearly increase in interior immigration enforcement over that time period raised the likelihood of living in poverty of households with U.S. citizen children by 4 percent. The effect is robust to a number of identification tests accounting for the potential endogeneity of enforcement policies, and is primarily driven by police-based immigration enforcement measures adopted at the local level such as $287(\mathrm{~g})$ agreements.

JEL Classification: $\quad 138, \mathrm{~J} 15, \mathrm{~K} 37$

Keywords: immigration enforcement, poverty, U.S. citizen children, unauthorized parents

Corresponding author:

Catalina Amuedo-Dorantes

Department of Economics

San Diego State University

San Diego, CA 92182

USA

E-mail: camuedod@mail.sdsu.edu 
"Are we a nation that kicks out a striving, hopeful immigrant $\{. .$.$\} or are we a nation that$ finds a way to welcome her in?"

President Barack Obama, November 2014

\section{Introduction}

This paper explores how the intensification of immigration enforcement at the local and state levels that has been taking place in the United States since 9/11 is impacting the poverty exposure of American children with unauthorized parents. In 2012, there were 4.5 million of U.S.-born children living with at least one unauthorized parent, doubled the number in 2002 (see Passel et al. 2014). Yet, unauthorized immigrants and their U.S.-born children account for 11 percent of the people living in poverty -about twice their population share. Given the importance of economic resources on children's health, education, and development outcomes later in life, ${ }^{1}$ understanding how the piecemeal approach to immigration enforcement is impacting the exposure to poverty of many U.S. citizen children is crucial for a well-informed debate of comprehensive immigration reform and for the design of policies that safeguard children's well-being.

There are several channels through which intensified enforcement can increase the exposure to life in poverty of households headed by unauthorized parents. First, tougher immigration enforcement can adversely impact the employment and earnings of unauthorized immigrants. Sometimes, this effect occurs through the implementation of employment verification mandates (E-Verify) aimed at restricting the employment opportunities of unauthorized immigrants. Nevertheless, the intensification of other immigration enforcement measures unrelated to employment, as in the case of Secure Communities, can also curtail the employment and earnings opportunities of unauthorized immigrants by exacerbating

\footnotetext{
${ }^{1}$ See, for example, Case et al. 2002, Almond and Currie 2011, Bailey and Dynarski 2011 or Levine and Zimmerman 2010, among others.
} 
deportation fears. In this vein, Amuedo-Dorantes et al. 2013 report how unauthorized immigrants have become more likely to indicate experiencing difficulties in obtaining social or government services, finding legal assistance, or obtaining health care services while in the United States. In other instances, they avoid seeking public services for fear of apprehension, even if their children were eligible for such services (Watson 2014). Hence, it is reasonable to foresee how intensified enforcement can steer families to live in the shadows in order to minimize apprehension risks. Such behavior can have labor market consequences, potentially leading them to forego profitable employment opportunities. ${ }^{2}$

Second, immigration enforcement can cause household income to plummet through the deportation of the main household earner, severely raising the household's exposure to life in poverty. By 2011, the number of fingerprints submitted through the 287(g) program had risen to 6.9 million from 828,119 in 2009 (Meissner et al. 2013). And, along with other police-based enforcement measures, the program had led to the identification of more than 373,800 potentially removable aliens between January 2006 and September 2014 (U.S. Immigration and Customs Enforcement). As a result, more than 1.8 million unauthorized immigrants were deported during the Administration of President Barack Obama alone (Vaughan 2013), with that number rising to more than 4.5 million since the U.S. Congress passed the Illegal Immigration Reform and Immigrant Responsibility Act of 1996 (IIRIRA) (Bergeron and Hipsman 2014).

We first assess the role of intensified interior immigration enforcement on the likelihood of life in poverty of households of U.S. citizen children with a likely unauthorized parent. To that end, we create a novel index of the intensity of immigration enforcement for the 2005 through 2011 period, which we merge to household-level data from the American

\footnotetext{
${ }^{2}$ Kostandini et al. (2013) document a decline in labor expenses in the farming sector (a sector that uses immigrant labor intensively) in U.S. counties where 287(g) agreements were signed because of a significant workforce reductions.
} 
Community Survey (ACS). To capture the intensity of immigration enforcement, we use population weighted indexes that exploit historical information on a variety of enforcement measures and initiatives at the local and state levels. Crucially, we exploit the geographical and temporal variation in the index to identify the impact of tougher immigration enforcement on poverty, as opposed to that of other macro-economic factors that may have contributed to the generalized poverty increase during the 2000-2009 decade (Peri 2013).

We find that a one standard deviation increase in the intensity of interior immigration enforcement (roughly twice the average yearly increase in this type of enforcement during the time period under examination) raises the likelihood of living below the poverty line of households of U.S. citizen children with at least one likely unauthorized parent by 4 percent and lowers their household incomes by 18 percent. Our findings are robust to a number of robustness checks and identification tests accounting for the potential endogeneity of enforcement policies, and suggest that the intensification of interior immigration enforcement is significantly curtailing the economic resources available to young generations of U.S. citizen children.

Subsequently, we exploit the heterogeneity in the nature of enforcement measures to learn about the underlying channels through which increased enforcement may be increasing household poverty. We find that police-based measures, particularly those adopted at the local level, are responsible for the increased poverty exposure of households of U.S. citizen children with a likely unauthorized parent. This finding is of particular interest because it highlights how, even though E-Verify mandates might adversely affect the employment and earnings of unauthorized immigrants, they are not necessarily causing these households to become poor. Rather, police-based measures, either by inducing unauthorized immigrants to accept poor job matches and working conditions for fear of deportation or by deporting the 
main household earner, are the ones mainly responsible for the observed impact of intensified enforcement on their poverty exposure.

Our study contributes to a growing body of work examining the impact of tougher immigration policies on unauthorized immigrants and their families in several important ways. First, the existing literature has focused on the direct economic impact of tougher immigration enforcement employment based measures (namely, employment verification or E-Verify mandates) on individual earnings. In that regard, Amuedo-Dorantes and Bansak (2012) find that E-Verify mandates reduce the employment of likely unauthorized immigrants, leading many of them to take jobs in industries benefiting from E-Verify exclusions, such as agriculture or food services. Likewise, Bohn and Lofstrom (2013) and Bohn et al. (2014), document that the 2007 Legal Arizona Workers Acts (LAWA) -which mandated, for the first time, all Arizona employers to use E-Verify- reduced the employment of likely unauthorized immigrants and raised self-employment among non-college Hispanic men. However, the broader effects of intensified police-based immigration enforcement on living standards through enhanced deportation fears or the deportation of main household earners have not been sufficiently explored. By looking at a wide spectrum of immigration enforcement measures for the 2005 through 2011 period at the local and state levels, our findings underscore how, beyond any direct impact of employment-based measures on employment and earnings, increased deportation fears stemming from intensified policebased enforcement, may have increased poverty exposure by: (1) leading unauthorized immigrants to live in the shadows, take worse jobs and accept poorer living conditions, and (2) increasing the likelihood of losing a main household earner to deportation.

Second, whether intensified immigration enforcement ends up raising the likelihood of life in poverty of American children with unauthorized parents is, ultimately, an empirical question that depends on the behavior of other members in the household. After all, the 
possibility exists for other household members to step in and increase their labor force participation in order to make up for any loss in income. By taking a household perspective, as opposed to an individual perspective, we address an important gap.

Finally, our findings add to the literature on the determinants of childhood exposure to poverty. Recent work by Bailey et al. (2014), Bitler et al. (2014) and Peri (2013) shows that child poverty drops with increased availability of family planning programs and higher unemployment rates, but it is independent of immigration shocks. We contribute to this literature by assessing the role of another set of policies -namely intensified immigration enforcement. In an election year, in which the debate and positions on immigration issues is becoming increasingly polarized, understanding the unintended consequences of an expanding piecemeal approach to immigration policy and enforcement is ever more relevant.

This paper is organized as follows. Section 2 contains a thorough description of the enforcement legislation over the timer period being examined. Section 3 discusses the enforcement and poverty data. Section 4 describes the methodology to identify the causal effect from increased employment. Section 5 presents the main findings, whereas section 6 investigates the channels through which increased enforcement may lead to increases in poverty. Section 7 concludes the study.

\section{Institutional Framework}

The Illegal Immigration Reform and Immigrant Responsibility Act of 1996 (IIRIRA) regulated some of what would become model measures of interior immigration enforcement over the past decade, such as the 287(g) agreements. Broadly speaking, interior enforcement initiatives over the past decades can be grouped into what we refer to as police-based measures involving the local or state police (e.g. 287(g) agreements, Secure Communities and omnibus immigration laws), and employment-based measures, which involve employers (i.e. employment verification mandates; henceforth E-Verify). Typically, police-based 
measures involve agreements between the Director of the Immigration and Customs Enforcement agency (ICE) and state and local (country, town, and city level) law enforcement agencies. These agreements allow designated officers to perform immigration law enforcement functions, provided that they have appropriate training and function under the supervision of ICE officers. Examples of law enforcement agencies which signed these agreements are Etowah County Sheriff's Office, Arizona Department of Corrections, City of Mesa Police Department, Pinal County Sherriff's Office. In contrast, E-verify mandates require employers to screen newly hired workers for work eligibility (see Appendix A for a detailed description of each of these measures). In what follows, we refer to both of these categories of immigration enforcement measures and to their relationship to poverty among households of U.S. citizen children with a likely unauthorized parent.

\section{Police-based Immigration Enforcement Measures}

Police-based immigration enforcement measures have evolved over time. We focus on three of them: 287(g) agreements, Secure Communities and omnibus immigration laws. Active since 2002, 287(g) agreements were one of the earliest police-based immigration enforcement measures. Unlike E-Verify, which is typically announced by a door sticker letting prospective employees know about the use of E-Verify in that company, migrants never know when the police might stop them and request proper identification. And, unlike E-Verify, police-based immigration enforcement measures are directly linked to deportations.

Police-enforcement measures provided local and state police officers the authority to interrogate any immigrant, arrest without warrant, and begin the removal process (under a "task force" agreement). They also allowed police officers to question immigrants who have been arrested about their immigration status (under a “jail enforcement” agreement). In 2006, only five counties partnered with the federal government. By 2008, that number had jumped to 41 counties (Wong 2012). Between 2006 and 2010, the budget for 287(g) 
increased from \$5 million to \$68 million, with over 1,500 state and local law enforcement officers trained and granted authorization to enforce federal immigration laws (Nyugen and Gill 2015).

In 2008, Secure Communities was introduced. The Secure Communities program (2008-2014), designed to replace the 287(g) agreements, prioritised immigration enforcement among non-citizens who had committed serious crimes. The fingerprints of detainees were checked against the databases from the Federal Bureau of Investigation (FBI) and from the Department of Homeland Security (DHS) in order to get information on past criminal arrests, convictions, and immigration history. By the end of 2013, all the nation's 3,181 jurisdictions were participating in Secure Communities (U.S. Immigration and Customs Enforcement (ICE) 2013). The Secure Communities program was replaced by the Priority Enforcement Program (PEP) in 2015, which continues to rely on fingerprint-based biometric data submitted by state and local law enforcement agencies and is mostly targeted to unauthorized immigrants convicted of specific crimes. ${ }^{3}$

In contrast to most 287(g) agreements and participation in the Secure Community program, which typically present a local nature, omnibus immigration laws (2010-present) are state-wide police-based enforcement measures. Arizona was the first state to sign an omnibus immigration law in 2010. While the content of each omnibus immigration law differs, they often include a "show me your papers' clause", which enables the police to request proper identification documentation during a lawful stop. Nonetheless, in some instances, omnibus immigration laws have gone as far as to require that schools verify

3

http://www.dhs.gov/sites/default/files/publications/14_1120_memo_secure_communities.pdf 
students' legal status. ${ }^{4}$ The first and only omnibus immigration law we are able to capture with our data is the "Support Our Law Enforcement and Safe Neighbourhoods Act" (henceforth SB1070), which was signed by Arizona’s governor on April 19, 2010. Deemed to be one of the tougher immigration laws on its day, SB1070 considers a crime not registering with the U.S. authorities if an immigrant has been living in the United States for more than 30 days, or if they do not have their documents with them all the times. It also requires state and local enforcement officers to check an individual's immigration status during a "lawful stop, detention or arrest" if there is suspicion that the person is an undocumented immigrant. By the end of April 2010, HB2162 was passed, amending SB1070 to avoid racial and ethnic profiling. One day before these laws were to become effective, the U.S. Department of Justice argued that SB1070 was unconstitutional and filed a lawsuit asking for an injunction against it. The law's most questionable provisions were blocked. ${ }^{5}$

\section{Employment-based Immigration Enforcement Measures}

Employment-based immigration enforcement is exemplified by employment verification mandates (E-Verify). E-verify is an electronic program that allows employers to screen newly hired workers for work eligibility. The program is administered by the U.S. Department of Homeland Security in partnership with the Social Security Administration. While the use of E-Verify is obligatory in the hiring of federal employees, it has been optional at other levels. Some states have mandated its use, either by public agencies and contractors working for public agencies or, in more extreme cases, by all employers in the state. The first E-Verify mandate was implemented in 2006 in the state of Colorado. With EVerify, the employer introduces the biographic information (name, social security number,

\footnotetext{
4 See Alabama's HB56, National Conference of State Legislatures 2012, http://www.ncsl.org/research/immigration/omnibus-immigration-legislation.aspx\#FiftyThree_Omnibus_Bills

${ }^{5}$ See: http://www.ncsl.org/research/immigration/analysis-of-arizonas-immigration-law.aspx
} 
date of birth, citizenship and alien registration number) of the prospective employee into an online program. The software program then cross-checks the prospective employee's records between those in the Social Security Administration (SSA) database and the records from the Department of Homeland Security (DHS) to determine whether the worker is authorised to work in United States. In the case that work eligibility is not confirmed, the employer receives a "tentative no confirmation" that the worker has to resolve within eight business days. By 2014, the number of employers enrolled in E-Verify had risen to 482,692. ${ }^{6}$

The E-verify program is far from perfect when detecting identity fraud, and it still renders a large number of false positives and negatives despite recent improvements. While false positives are often related to document fraud, false negatives occur when the system fails to confirm the eligibility to work in the United States of someone authorized to do so, either due to errors in the way the employer entered the information, or to out-dated, missing and/or erroneous information in the federal database (see Meissner et al. 2013).

\section{Data}

Our main aim is to explore the impact that intensified interior immigration enforcement is having on the likelihood that households of American children with likely unauthorized parents live in poverty. To that end, we use household-level data from the U.S. Census Bureau’s American Community Survey (ACS), along with local and state level data on the implementation of the following immigration enforcement measures: E-Verify mandates, 287(g) agreements, omnibus immigration laws and the Securities Communities program.

\footnotetext{
${ }^{6}$ See: http://www.uscis.gov/e-verify/about-program/history-and-milestones
} 


\subsection{The American Community Survey}

The ACS data is a yearly national survey conducted by the U.S Census Bureau produced by the Integrated Public Use Microdata Series (Ruggles et al. 2010). Every year approximately 3.5 million randomly sampled households take part, of which 24,000 are households of U.S. citizen children with an unauthorized parent.

The ACS dataset is especially well-suited for the purpose of this paper for various reasons. First, it contains detailed information on the outcome of interest to this study namely household poverty. Our main dependent variable, a dummy for whether the household lives in poverty, takes the value of 1 if household income falls below the poverty line, and 0 otherwise (e.g. Bailey et al. 2014). This variable is created directly by ACS using detailed income and family structure information, as well as the poverty line established by the Social Security Administration. In 2010, the poverty line for a family of four (two adults plus two children) was $\$ 22,113$. There are, however, a couple of important drawbacks to the official poverty measure (Bitler, Hoynes, and Kuka 2014). The first one is the fact that the line does not vary geographically, even though it is inflation adjusted using the Consumer Price Index (CPI). The second drawback is that the line only refers to money income before taxes. It does not include capital gains or noncash benefits, such as public housing, Medicaid, and food stamps. This is, however, less likely to prove of relevance in the case of households of children with likely unauthorized parents, as many of them might not apply for such benefits owing to their undocumented status (Watson 2014). Nevertheless, to address these potential limitations, we also consider alternative measures, including a dummy variable indicative of whether the household's income falls below 1.5 times the poverty line, the logarithm of real household income and the household's participation in the Food Stamp program. 
In addition to information on household poverty, the ACS contains rich sociodemographic information that can play a decisive role in understanding children's poverty exposure, such as the number of years parents have lived in the United States. But key to our analysis is the fact that the ACS consistently identifies the geographic location of households at a fine level, allowing us to exploit the geographic and temporal variation of immigration policies. Specifically, the area of analysis in the ACS is the Consistent Public Use Microdata Area (CONSPUMA), which contains several towns, cities and counties. In total, there are 543 geographic local areas (CONSPUMAs) covering the entire United States.

For the purpose of the study, we focus on families with at least one U.S.-citizen child between 0 and 18 years of age living in the household during the 2005-2011 waves. These are the ACS waves that provide information on the CONSPUMAs in which the household resides (after 2012, the ACS stopped identifying the CONSPUMAs). Additionally, we restrict our attention to households where, at least, one parent is likely unauthorized. Because, like all official representative datasets, the ACS does not contain information on the migrant's legal status, we rely on Hispanic ethnicity and lack of citizenship, shown to be good predictors of immigrants' unauthorized status (Passel and Cohn 2009, 2010), to proxy for the parents' likely unauthorized status. ${ }^{7}$

Table 1 presents some summary statistics for our sample. We work with roughly 150,000 households of U.S. citizen children with likely unauthorized parents. About 32 percent of them live in poverty -a share that rises to 54 percent when we consider a broader definition of poverty. Average household income for these households in 1999 constant dollars amounts to $\$ 24,100$ over the time period under consideration, and 22 percent of households participated in the Food Stamps program. Importantly, Table 1 underscores some

\footnotetext{
${ }^{7}$ In our robustness checks, we experiment with alternative definitions of our sample to more accurately capture the population who is unauthorized. Results prove robust to the use of these alternative sample definitions.
} 
household traits likely correlated to poverty. Specifically, 24 percent of households in our sample are single headed, and only 17 percent of them have a household head with, at least, a High School diploma. Approximately 47 percent of household heads do not speak English at all or do not speak it well, even though, on average, they have resided in the United States for approximately 13 years. Still, the vast majority works (76 percent of them). And, on average, they are 35 years old and have roughly two children living in the household. The descriptive statistics in Table 1 also inform about some average characteristics of the CONSPUMAs where these households reside. Unemployment rates in those CONSPUMAs averaged 8 percent over the time period under consideration and, back in 1980, the share of low-skilled workers in sectors more likely to hire unauthorized workers was not that different, fluctuating between 69 percent in manufacturing and 78 percent in services. To conclude, the share of the electorate voting for Republican candidates for the U.S. House of Representatives in the states were the CONSPUMAs were situated averaged 46 percent. ${ }^{8}$

\subsection{Enforcement Data}

We gather data on the implementation of the following interior immigration enforcement initiatives: local and state level 287(g) agreements with ICE, local participation in Secure Communities, state level E-Verify mandates and omnibus immigration laws. Specifically, data on the 287 (g) agreements signed at either the local or state level is gathered from ICE’s 287(g) Fact Sheet website (U.S. Immigration and Customs Enforcement 2015) and from Amuedo-Dorantes and Puttitanun (2014), and Kostandini et al. (2013). Data on participation in Secure Communities program is gathered from the 2013 ICE's Activated Jurisdictions document, which contains detailed information on the rollout of the Secure Communities program across counties in the United States between 2008 and 2013 (U.S. Immigration and Customs Enforcement 2013). Information on the implementation dates of

\footnotetext{
${ }^{8}$ Detailed information on the various variables can be found in Appendix B.
} 
E-Verify mandates and omnibus immigration laws is gathered from the National Conference of State Legislatures’ website (Legislatures 2012).

It is worth noting that immigrant families in a given CONSPUMA may be exposed to a multiplicity of immigration enforcement measures. For example, someone residing in Etowah county, Alabama, in 2009 was exposed to a local 287(g) jail enforcement program adopted by the Etowah county's sheriff office and a 287(g) task force program adopted by the Department of Public Safety of Alabama. To address the multiplicity of measures to which individuals are exposed to, we compute five indices -one for each enforcement initiative.

Following Watson (2013) and Amuedo-Dorantes and Lopez (2015), we use an interior immigration enforcement index for each CONSPUMA $c$ in each year $t$ (Enforcement Index E $_{c, t}$ ), equal to the sum of five enforcement indices corresponding to each enforcement policy for each CONSPUMA and year as:

$$
E I^{K}{ }_{c t}=\frac{1}{N 2000} \sum_{a \in A}^{A} \frac{1}{12} \sum_{\boldsymbol{m}=\mathbf{1}}^{12} \mathbf{1}(E m, a) P_{a, 2000}
$$

where $E I^{K}$ refers to the enforcement index relating to type $K$ of immigration enforcement measure in question -that is, $K$ stands for whether the measure is a local 287(g) agreement, participation in the Secure Communities program, a state level 287(g) agreement, an omnibus immigration law or an E-Verify mandate. The sub-index $a$ refers to a given city (or town) in CONSPUMA $c$, ${ }^{9}$ whereas $m$ stands for month of year $t$. Thus, $\mathbf{1}(E m, a)$ is an indicator function that takes the value of 1 if one of the immigration enforcement initiatives being looked at was in effect in city $a$ and month $m$. It takes the value of 0 if the measure was not in place, the value of 1 if it was in place year round or, otherwise, a value equal to the a fraction equivalent to the number of months in that year when the measure was in place. For

\footnotetext{
${ }^{9}$ Local areas (CONSPUMAs) may include several cities, towns, or counties. Local law enforcement agencies typically operate at the County, City or Town level and can only belong to a single CONSPUMA.
} 
each type of immigration enforcement policy, the indicator: $\mathbf{1}(E m, a)$ is then weighted by the population $P_{a, t}$ in city $a$ and year $t$, which is obtained from the 2000 Census. $N$ stands for the population in each CONSPUMA $c$, calculated as the sum of the population in all cities and towns belonging to that CONSPUMA -that is: $N 2000=\sum_{\boldsymbol{a}=\mathbf{1}}^{A} P_{a, 2000}$, where $A$ is the total number of cities (and towns) in the CONSPUMA.

Our final enforcement index is the sum of each of the indices constructed for each of the five policy measures by CONSPUMA and year. ${ }^{10}$ Since we look at 5 different policy initiatives -namely: local 287(g) agreements, local participation in Secure Communities, state 287(g) agreements, state level employment verification mandates and state level omnibus immigration laws, the interior immigration enforcement index could take values between 0 and 5. As shown in Table 1, the interior immigration enforcement index over the time period under consideration averaged 0.37 and fluctuated between 0 (i.e. no enforcement) and 4.18. And while, on average, local and state level immigration enforcement measures seem to be equally dominant, police-based measures were, without a doubt, more prevalent than employment-based measures.

To provide a sense of the evolution of interior immigration enforcement during the time period under consideration, Panels A-C in Figure 1 shows the roll out of immigration enforcement measures between 2004 and 2010. Lighter colours correspond to lower levels of enforcement (captured by the interior immigration enforcement index $E I_{c, t}$ ) in CONSPUMA $c$ in year $t$. Enforcement levels in the United States increased almost ten-fold during this period. In 2004, only 25 CONSPUMAs had an enforcement index greater than zero, whereas

${ }^{10}$ For example, if a CONSPUMA is comprised of 2 cities with distinct participation in the Secure Communities program, the SC index assigned to CONSPUMA $c$ in year $t$ would be given by: SC index $=[($ months of participation in SC $/ 12) *$ (Population of City \#1/County Population) + (months of participation in SC /12) * (Population of City \#2/County Population)]. 
the majority of CONSPUMAs (515) had an enforcement index equal to 0 (i.e., no enforcement). By 2007, the number of CONSPUMAs without any interior immigration enforcement had dropped to 476 and, by 2010, to 255 . In addition, the intensity of immigration enforcement in many CONSPUMAs with some existing measure in place increased over time. The CONSPUMAs experiencing the largest increase in interior immigration enforcement during this period were located in Virginia, North Carolina, California and Utah. In contrast, CONSPUMAs located in states like North Dakota, Maine, Indiana or Wyoming did not experience an increase in enforcement regulation over this period, and their enforcement levels were still fairly low in 2010. CONSPUMAs in Florida were the only ones whose immigration regulation eased up during this time, although they started off with a relatively high regulatory environment.

Because, depending on their scope and design, one can foresee a differential impact of the interior immigration enforcement initiatives being examined, we also experiment with grouping the indexes in various ways. Specifically, we distinguish between employmentbased immigration enforcement initiatives (exemplified by employment verification mandates applied by employers), and what we refer to as police-based measures (as in the case of 287(g) programs, Secure Communities and state omnibus immigration laws that involve the participation of the local or state police). In other instances, the indexes are grouped so as to distinguish between local level initiatives -as in the case of most 287(g) agreements and participation in the Secure Communities program, and state level ones -as would be the case with a few state level 287(g), E-Verify mandates and omnibus immigration laws.

\section{Methodology}

We are interested in examining the impact of intensified interior enforcement on the probability that household income falls below the poverty line for households with at least 
one U.S.-citizen child and one likely unauthorized parent. To achieve this aim, we exploit the geographic and temporal variation in interior enforcement measures. Our benchmark model is given by:

$$
y_{h, c, t}=\alpha+\beta_{1} E I_{c, t}+X_{h, c, t}^{\prime} \beta_{2}+Z_{c, t}^{\prime} \beta_{3}+W_{c, 1980}^{\prime} \beta_{4}+W_{c, 1980}^{\prime} t \beta_{5}+\gamma_{c}+\theta_{t}+
$$

$+\gamma_{c} t+\varepsilon_{h, c, t}$

where $y_{h, c, t}$ is a dummy variable indicative of whether income for household $h$, in CONSPUMA $c$ in year $t$ was below the poverty line. We also experiment with alternative definitions of household poverty, as well as other alternative dependent variable such as household income and Food Stamp receipt in our robustness checks.

The enforcement index in CONSPUMA $c$ and time $t\left(E I_{c, t}\right)$ is our key regressor. As noted earlier, it captures the intensity of local and state level immigration enforcement in CONSPUMA $c$ at time $t$. Additionally, equation (2) includes the vector $X_{h, c, t}$, which accounts for a range of household characteristics known to be potentially correlated with household income and poverty exposure. The latter include dummy variables for whether the household is a single headed household, as well as indicators for the age, lack of English proficiency, educational attainment, employment and years of U.S. residency of the household head, and information on the number of children residing in the household.

Equation (2) also incorporates a number of CONSPUMA-specific and time-varying characteristics $\left(Z_{c, t}\right)$ potentially influencing household income and its exposure to poverty, as could be the case with unemployment rates. Likewise, to address concerns regarding the possibility that the coefficient on the enforcement index might be capturing the role played by other local area characteristics, such as the political inclination of the electorate, the vector $Z_{c, t}$ also includes the share of the electorate voting Republican in the last congressional elections. 
In addition to the aforementioned time-varying local area characteristics, equation (2)

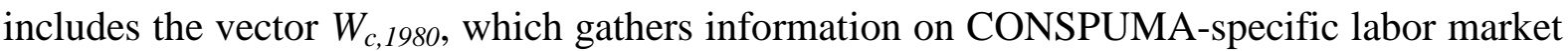
characteristics potentially correlated with poverty rates from 1980. Specifically, information on the share of low-skilled (defined as non-college educated) in agriculture, service, manufacturing, and construction sectors is incorporated. We also interact those variables with a linear time trend to control for differential trends in these regressors possibly correlated with the timing of the adoption of immigration laws. ${ }^{11}$

To conclude, equation (2) also includes geographic and temporal fixed-effects, as well as area-specific time trends. The geographic fixed-effects $\left(\gamma_{c}\right)$ address unobserved and timeinvariant CONSPUMA-specific characteristics potentially correlated with household income and the household's exposure to poverty, as could be the case if the household resides in an economically depressed area. The temporal fixed-effects, captured by $\theta_{t}$, account for aggregate level shocks potentially impacting poverty, as could have been the case with the 2008-2009 downturn. Finally, we include area-specific time trends $\left(\gamma_{c} t\right)$ to capture a variety of unobserved time-varying characteristics at the CONSPUMA level that might not be addressed by the controls included in $Z_{c, t}$. In all regressions, the standard errors are clustered at the CONSPUMA level. ${ }^{12}$

Our coefficient of interest is $\beta_{1}$, which captures the relationship between the intensity of immigration enforcement and the household's income and poverty exposure. A negative coefficient would be consistent with the hypothesis that tougher enforcement increases the economic difficulties experienced by the families of U.S. citizen children with likely unauthorized parents.

\footnotetext{
${ }^{11}$ See Appendix B for greater detail on the key variables being used.

${ }^{12}$ We also experiment with clustering the standard errors at the broader state level. Results prove robust to this alternative clustering.
} 


\section{Results}

\subsection{Main Findings}

The results from estimating equation (2) using ordinary least squares on the sample of households with U.S.-citizen children and, at least, one undocumented parent are displayed in the first four columns of Table 2. We estimate a number of specifications that progressively add controls. According to the estimates in the fourth and most complete model specification in Table 2, a one standard deviation increase in the immigration enforcement index raises the likelihood that a household of U.S. citizen children with, at least, one likely unauthorized parent lives in poverty by 1.3 percentage points or 4 percent. $^{13}$

The remaining coefficient estimates in Table 2 look as expected. For example, residing in a single headed household raises the likelihood of living in poverty by as much as 25 percentage points. Similarly, having a household head who does not speak English or does not speak it well raises the likelihood of household poverty by 11 percentage points. The number of children in the household also matters, with each additional child raising the likelihood of life in poverty by close to 7 percentage points. In contrast, having a household head who is older, more educated, employed or a long-time resident of the United States significantly lowers the poverty risk.

Because some of the intensification of immigration enforcement occurred during the 2008-2009 recessionary years, one might be concerned about the possibility that the measured impact is capturing the effects of the economic downturn on poverty. Note that, if that were the case, we should be able to see alike effects on other migrant households with U.S.-born children; even if they happen to be naturalized and, therefore, should not have been negatively impacted by the intensification of immigration enforcement. In sum, can we

\footnotetext{
${ }^{13}$ According to the descriptive statistics in Table 1, the standard deviation of the enforcement index is 0.64 . The average share of children living below the poverty line is 0.32 or 32 percent.
} 
conclude that the observed impacts unique among households of American children with likely unauthorized parents? To answer that question, we re-estimate equation (2) using a sample of households with U.S. citizen children whose parents are naturalized and, therefore, should not be negatively impacted by the intensification of immigration enforcement. The results from this exercise are displayed in Table 3. Regardless of the specification and estimation methodology being used, there is no evidence of a significant impact of immigration enforcement on the poverty exposure of these families. Yet, the remaining determinants of childhood poverty across Tables 2 and 3 are rather similar. ${ }^{14,15}$

\subsection{Identification and Falsification Tests}

The validity of the findings in Table 2 depends on a number of assumptions made when assessing the impact of intensified immigration enforcement on the poverty exposure of households of U.S. citizen children with, at least, one likely unauthorized parent. In this section, we refer to each of these assumptions and explore whether they are being fulfilled in our case.

\subsubsection{Parallel Trends Assumption}

The analysis in Table 2 assumes that poverty trends of households of U.S. citizen children with a likely unauthorized parent (treated households) and households of U.S. citizen children with naturalized parents (control households) prior to the intensification of interior immigration enforcement were parallel. To test that assumption, we pool treated and control households and estimate Equation (3) with a full set of dummies going from four years before to four years after the enforcement index turns positive. The dummies are, in

\footnotetext{
${ }^{14}$ We obtain similar results when, instead of families of U.S.-born children with naturalized parents, we focus on families of U.S.-born children with native parents.

${ }^{15}$ The results from table 2 are not sensitive to the exclusion of 2009 or Maricopa County, AZ, from our sample.
} 
turn, interacted with a dichotomous variable indicative of whether the household is one with likely unauthorized parents $\left(L U_{h}\right)$ as follows:

(3) $y_{h, c, t}=\alpha+\sum_{i=-4}^{4} \beta_{i} D_{i} * L U_{h}+\sum_{i=-4}^{4} \beta_{i} D_{i}+\varphi L U_{h}+X_{h, c, t}^{\prime} \delta+Z_{c, t}^{\prime} \mu+\gamma_{c}+$ $\theta_{t}+\gamma_{c} t+\varepsilon_{h, c, t}$

where $D_{i}$ is a dummy for the $i$ th year before (-i) or after (i) the enforcement index first turns positive. In the absence of any pre-existing differential poverty trends between treated and control households, the estimated coefficients on the interaction terms corresponding to the years prior to the activation of tougher enforcement should be non-statistically different from zero.

Table 4 shows the estimates from equation (3). None of the coefficients on the interaction terms for the years preceding the implementation of tougher immigration enforcement are statistically different from zero. The positive impact of intensified enforcement on the poverty exposure of families with U.S. citizen children and, at least, one likely unauthorized parent, does not emerge until the measures were implemented. As such, there is no evidence of a differential pre-trend in the incidence of poverty among households of U.S. citizen children with a likely unauthorized parent and households of U.S. citizen children with naturalized parents.

\subsubsection{Endogeneity of Immigration Enforcement}

Another potential concern with the estimates in Table 2 refers to the potential endogeneity of interior immigration enforcement with respect to the incidence of poverty. Endogeneity can stem from various sources, including the non-random adoption of enforcement measures by CONSPUMAs or the non-random residential choices made by unauthorized immigrants, who might prefer to settle in CONSPUMAs with lesser enforcement. In both instances, the level of interior immigration enforcement to which the migrant is exposed to would not be exogenously determined. To address this concern, we 
perform a couple of identification tests. First, we assess if the implementation of tougher interior immigration enforcement, even if not random, is uncorrelated to the incidence of poverty among households of U.S. citizen children with a likely unauthorized parent -as needed for identification purposes. To assess if that is a valid assumption, we follow La Ferrara et al. (2012) and aggregate the data at the CONSPUMA level to estimate the following model:

$$
E I Y e a r_{c}=\alpha+X_{c}^{\prime 2000} \alpha+Z_{c}^{\prime 2000} \mu+\lambda W_{c}^{2000}+\varepsilon_{c}
$$

where $E I$ Year $_{c}$ is the first year when the enforcement index turned positive in CONSPUMA $c$, and $X_{c}^{2000}$ are the same vectors of household characteristics in Equation (2) aggregated at the CONSPUMA level, thus reflecting average CONSPUMA characteristics before any measure came into effect, i.e. in the year 2000. We also control for $Z_{c}^{2000}$, which contains the unemployment rate in 2000, the 1980-share of low-skilled workers employed in various sectors, and the share voting Republican in the state to which CONSPUMA $c$ belongs in 2000. Most importantly, the vector $W_{c}^{2000}$ is the share of Hispanic families living in poverty in CONSPUMA $c$ in 2000. We estimate equation (4) with and without Metropolitan Statistical Area (MSA) fixed-effects. The errors are being clustered at the MSA level. In the absence of selection effects, we should find that the coefficient $\lambda$ is not statistically different from zero.

Table 5 presents the results from that exercise. Regardless of the specification being used, we fail to see any statistically significant relationship between past poverty levels in the CONSPUMA (that is, prior to the implementation of tougher immigration enforcement levels) and the timing of tougher immigration enforcement. In other words, CONSPUMAs with higher poverty rates among households of U.S. citizen children with a likely unauthorized parent do not appear to have self-selected themselves into tougher immigration enforcement. 
As a second test for the potential endogeneity of immigration enforcement, we explore the possibility that our results might be biased by the potentially endogenous residential location of migrants. One could imagine that households with, at least, one likely unauthorized parent would be sensitive to immigration enforcement due to fear of deportation. Because migrants, especially unauthorized ones, are a relatively mobile population, they are likely to move in response to the adopted enforcement measures. ${ }^{16}$ As such, we may find that tougher immigration enforcement does not significantly impact the household incomes or likelihood of life in poverty of families of U.S. citizen children with likely unauthorized parents

To gauge if that is the case, we experiment with an alternative measure of immigration enforcement that is derived using information on the historical location of similar likely unauthorized immigrants prior to the rolling of tougher immigration enforcement measures. Specifically, we exploit the entrenched tendency for immigrants to locate in areas with established networks of their countrymen (Bartel 1989; Massey et al. 1993; Munshi 2003; Card 2001; Cortés and Tessada 2010, among many others) to proxy for what might have been their likely location in the absence of tougher interior immigration enforcement. ${ }^{17}$ Even though the earliest immigration enforcement initiative examined herein -namely the 287(g) agreements- was not signed until 2002 by the state of Florida, 287(g) were regulated in the Illegal Immigration Reform and Immigrant Responsibility Act of 1996. Therefore, we look at where similar likely unauthorized parents chose to reside at a much earlier date, i.e. in 1980. Looking at the location of alike migrants in excess of 20 years

\footnotetext{
${ }^{16}$ In this vein, the enactment of HB56 in Alabama -Alabama's omnibus immigration lawresulted in the overnight flight of many Hispanic children from its public schools and created serious concerns among school administrators. See, for example: http://neatoday.org/2011/08/31/alabama-schools-worry-about-effects-of-immigration-law/ 17 Indeed, despite the emergence of new immigrant locations during the 1990s, the vast majority of immigrants continued to locate in traditional states, such as California, Texas, Florida or New York/New Jersey.
} 
ahead of the time when the first measures are implemented (i.e. 2002) also allows us to address any concerns regarding the role that economic conditions not captured by the CONSPUMA unemployment rates, past labor market composition, fixed-effects or specific time trends could be playing in the location of the household and in how well the household does economically. We then construct the following share to proxy for what the residential location of households in our sample would have been based on the location of similar likely unauthorized household heads from the same countries of origin $o$ in the 1980 Census:

(5) Share of Undocumented Immigrant Im,, $1980=\frac{\text { undocumented immigrants }_{c, 0,1980}}{\text { undocumented }_{\text {immigrants }}, 1980}$

The constructed shares are interacted with the corresponding immigration enforcement index for each CONSPUMA $c$ for each year in question to derive a predicted measure of the immigration enforcement to which each household would have been exposed to. Using that new immigration enforcement index, we estimate equation (2) to assess the degree to which our results might be biased by the potentially selective residential location of migrants.

Table 6 displays the estimates using the historical location of comparable immigrants as a proxy for the current location of households of U.S. citizen children with likely unauthorized parents. The estimates in Table 6 closely match those in Table 2. A one standard deviation increase in the new enforcement level to which households in our sample would be exposed to had they located following historical residential patterns (equal to 0.13) would raise their likelihood of life in poverty by 1.3 percentage points or 4 percent. As a result, the estimates in Table 2 do not seem be significantly biased.

\subsection{Further Robustness Checks}

Once checked the proper identification of the impact of intensified immigration enforcement, we proceed to perform a number of robustness checks intended to assess the sensitivity of our findings to the use of alternative measures of poverty and different samples 
of households -some of which might be considered a better proxy of households with a likely unauthorized parent. Overall, the robustness checks in Tables 7 and 8 reveal that our results are qualitatively and quantitatively the same, regardless of the poverty measure being used or sample restrictions being imposed.

Specifically, Table 7 displays our findings for the sample of households with a likely unauthorized parent and for similar households with naturalized parents, respectively, using alternative measures of poverty exposure. As noted earlier on, a common criticism is that the official poverty level is too low and that, on average, families need an income of about twice the federal poverty level just to afford basic expenses (Bitler et al. 2014). Therefore, in Table 7, we experiment with using as dependent variables: (a) a dummy equal to 1 if the household had an income that fell below 1.5 times the poverty line (Panels A); (b) the logarithm of real household income (Panel B), and (c) a dummy equal to 1 if the household participated in the Food Stamps program (Panel C).

The estimates continue to be rather consistent. Focusing on the most complete specification, we can conclude that a one standard deviation increase in immigration enforcement leads to increases in the likelihood that household income is below 1.5 times the poverty line in the order of 1.3 percentage points or 2.5 percent. Similarly, the same increase in immigration enforcement would yield the equivalent of an 18 percent drop in household income and raise the likelihood of participation in the Food Stamps program by 7 percent. In contrast, none of these impacts are observed when we look, instead, at similar families where the parents are naturalized.

We also experiment with performing the analysis using alternative definitions of what might be consider a household with a likely unauthorized parent in Table 8. In Panel A of Table 8, we focus on families of U.S. citizen children with, at least, one likely unauthorized parent with more than 5 years residing in the United States. Doing so allows us to address 
any concerns regarding the possibility that some likely unauthorized parents -defined as Hispanic non-citizens- might include individuals with non-immigrant visas -typically shorter than 5 years in duration. Next, in Panel B, we consider households of U.S. citizen children with a likely unauthorized parent who, in addition, does not have a high school diploma. Finally, in Panel C, we consider restricting the sample to households of U.S. citizen children with, at least, one likely unauthorized parent who is less than 45 years of age. Doing so, eliminates individuals who might have, otherwise, legalized under the 1986 Immigration Reform and Control Act. In all instances, we continue to find similar results. Namely, a one standard deviation increase in immigration enforcement raises the likelihood of life in poverty for these sets of households by approximately 1.7 percentage points (6 percent), 1.8 percentage points (5 percent), and 1.3 percentage points (4.2 percent), respectively.

\section{Channels for the Observed Policy Impacts}

So far, we have established that the intensification of interior immigration enforcement significantly lowered household income and raised the poverty exposure of households with U.S. citizen children and a likely unauthorized parent. However, of the various measures in place, which have been more damaging to these families? From a policy perspective, if intensified immigration enforcement is raising the likelihood of life in poverty among households of U.S. citizen children with likely unauthorized parents, we would wish to learn about the type of immigration enforcement initiatives most likely responsible for the found impacts. Are the effects of local enforcement initiatives more salient than those of state level ones? This could be the case if, somehow, local level measures seems to be more intensively enforced than state level measures. Or if, alternatively, immigration enforcement initiatives at the local and state level differ with regards to their police-based versus employment-based nature. Indeed, employment-based initiatives, exemplified by the 
employment verification mandates, are state-wide measures. Is the nature of the policy itself -namely, whether it involves the police or, rather, employers- that matters most?

To address the aforementioned questions, we distinguish according to the geographic scope of the enforcement measure, as well as by whether or not the measure involves the police or, rather, employers. Results from this exercise are displayed in Table 9. As in Table 2, we estimate a number of model specifications that progressively add controls. According to the most complete specification in column 4 of Panel A, local policies seem more relevant than state level policies at impacting households’ poverty exposure. A one standard deviation increase in local level enforcement (approximately 0.27) raises the likelihood of life in poverty by approximately 1 percentage point or 2.5 percent. However, the impact of intensified immigration enforcement initiatives at the state level is not statistically different from zero at conventional levels. There could be various explanations for this finding -one of them being the type of policy -police-based or employment-based-typically adopted at the state and local levels.

To clarify the findings from Panel A, in Panel B we look at the role played by various intensified immigration enforcement depending on whether it involves the police or, rather, employers. According to the estimates in the last column of Panel B, police-based measures more directly linked to apprehension and deportation seem to play a greater role in raising poverty among our sample of households. Specifically, a one standard deviation increase in such measures (approximately equal to 0.45 ) raises the likelihood of life in poverty by 1 percentage point or 3 percent. ${ }^{18}$ The effect of employment-based measures, exemplified by state level employment verification mandates, is estimated less precisely and is not

\footnotetext{
${ }^{18}$ Testing reveals that the impacts of state and local policies are statistically different from each other. Likewise, the estimated impacts of employment-based versus police-based measures seem to be statistically different. Tests are available from the authors.
} 
statistically different from zero at conventional levels, although the magnitude of the coefficient is similar.

The above findings are not surprising. The vast majority of unauthorized immigrants are employed in the underground or informal economy, where the use of E-Verify is null -as would be the case with women working as nannies and housekeepers, or with men having their own repair or construction business. In other instances, unauthorized migrants work in sectors that are exempted from the use of E-Verify -as would be the case with firms in the private sector in the most common instance of the mandate referring to public sector employers or contractors. And, even in the more unique case of having a universal E-Verify mandate, a number of employees are excluded from the use of E-Verify if they have shortterm contracts (as in agriculture and construction) or work in small businesses with fewer than 10 employees (as it is often the case in retail or food \& drink entrepreneurship). Therefore, it is not surprising that state level employment-based mandates have a much smaller impact on the poverty exposure of our sample of households.

In sum, the estimates in Table 9 suggest that police-based measures, particularly those at the local level, are the ones driving the observed negative impacts of intensified immigration enforcement on the poverty exposure of households of U.S. citizen children with, at least, one likely unauthorized parent. This finding is consistent with the idea that, unlike E-Verify mandates, police-based enforcement is directly linked to apprehension and deportation. Furthermore, unlike employment-based enforcement, police-based enforcement cannot be easily evaded by seeking a job in the private sector (if the mandate only refers to public employers) or in the informal sector (if the mandate refers to all employers, public and private). As such, it is more likely to induce families to live in the shadows, trying to minimize their exposure to the police, taking worse jobs if needed and, overall, accepting worse living conditions. 


\section{Summary and Conclusions}

The past two decades have witnessed an escalation of interior immigration enforcement at both the local and state levels. Using data from the American Community Survey (ACS) and an enforcement index created using data on a number of state level and local immigration enforcement initiatives for the period 2005-2011, we explore the impact that intensified enforcement has had on the poverty risk of families of U.S. citizen children with likely unauthorized parents. We find that tougher enforcement is associated with lower family income and a higher probability of life in poverty, with most of the impact originating from local police-based measures, such as $287(\mathrm{~g})$ agreements and the Secure Communities program. Our results prove robust to a number of identification and robustness checks.

Given the strong relationship between the household income of children and children's future adult outcomes, the fact that U.S. citizen children with likely unauthorized parents account for roughly 8 percent of all American children, and the still pending comprehensive immigration reform, public awareness of the unintended consequences of intensified enforcement on these households' incomes and poverty exposure is imperative. With this study, we hope to shed some light on this crucial relationship and stimulate further research into the role that a piecemeal approach to immigration enforcement is having on the social and economic fabric of this country and on future generations of Americans. 


\section{References}

Almond, Douglas, and Janet Currie. 2011. "Human Capital Development before Age Five.” In Handbook of Labor Economics, edited by eds In O. Ashenfelter and D.Card, 13151486. Maryland Heights, MO:Elsevier.

Amuedo-Dorantes, Catalina, and Cynthia Bansak. 2012. “The Labor Market Impact of Mandated Employment.” American Economic Review: Papers \& Proceedings 102 (3): 543-48.

Amuedo-Dorantes, Catalina, and Mary J Lopez. 2015. “Faling Through the Cracks? Grade Retention and School Dropout among Children of Likely Unauthorized Immigrants.” American Economic Review: Papers \& Proceedings 105 (5): 598-603.

Amuedo-Dorantes, Catalina, and Thitima Puttitanun. 2014. "Remittances and Immigration Enforcement.” IZA Journal of Migration 3:6.

Amuedo-Dorantes, Catalina, Thitima Puttitanun, and Ana P Martinez-Donate. 2013. "How

Do Tougher Immigration Measures Affect Unauthorized Immigrants?” Demography 50 (3): 1067-91.

Bailey, Martha J, and Susan M Dynarski. 2011. “Gains and Gaps: Changing Inequality in U.S. College Entry and Completion.” NBER Working Paper Series 17633.

Bailey, Martha J, Olga Malkova, and Johannes Norling. 2014. “Do Family Planning Programs Decrease Poverty? Evidence From Public Census Data.” CESifo Economic Studies 60 (2): 312-37.

Bergeron, Claire, and Faye Hipsman. 2014. “The Deportation Dilemma: Reconciling Tough and Humane Enforcement.” Washington, DC. Migration Policy Institute

Bitler, Marianne, Hilary Hoynes, and Elira Kuka. 2014. “Child Poverty and the Great Recession.” Under Review. 
Bohn, Sarah, and Magnus Lofstrom. 2013. “Employment Effects of State Legislation against the Hiring of Unauthorized Immigrant Workers.” In Immigration, Poverty, and Socioeconomic Inequality, edited by David Card and Steven Raphael. Russell Sage.

Case, Anne, Darren Lubotsky, and Christina Paxson. 2002. "Economic Status and Health in Childhood: The Origins of the Gradient." American Economic Review 92 (5): 1308-34. Kostandini, G., E. Mykerezi, and C. Escalante. 2013. “The Impact of Immigration Enforcement on the U.S. Farming Sector.” American Journal of Agricultural Economics 96 (1): 172-92. doi:10.1093/ajae/aat081.

Legislatures, National Conference of State. 2012. "State E-Verify Laws.” http://www.ncsl.org/research/immigration/everify-faq.aspx\#2012 State Action.

Levine, Phillip B, and D.J Zimmerman. 2010. "Introduction to“ Targeting Investments in Children: Fighting Poverty When Resources Are Limited.’” In Targeting Investment in Children: Fighting Poverty When Resources Are Limited, edited by Phillip B Levine and D.J Zimmerman, 3-11.

Meissner, D., D.M Kerwin, M. Chishti, and C. Bergeron. 2013. “Immigration Enforcement in the United States : The Rise of a Formidable Machinery.” Technical Report, Migration Policy Institute.

Passel, Jeffrey S, and D’Vera Cohn. 2011. “Unauthorized Immigrant Population : National and State Trends , 2010.” PewResearchCenter. Pew Hispanic Center. Washington, D.C. Passel, Jeffrey S, D’Vera Cohn, and Molly Rohal. 2014. “Unauthorized Immigrant Totals Rise in 7 States, Fall in 14: Decline in Those From Mexico Fuels Most State Decreases.” Pew Research Center’s Hispanic Trends Project, November. Washington, DC.

Passel, Jeffrey S., and D’Vera Cohn. 2009. “A Portrait of Unauthorized Immigrants in the United States.” Pew Research Center Report, i - 42.

—. 2010. "US Unauthorized Immigration Flows Are Down Sharply Since Mid-Decade.” 
Pew Hispanic Center. Washington, D.C.

Peri, Giovanni. 2013. “The Impact of Immigration on Native Poverty.” In Immigration,

Poverty, and Socioeconomic Inequality, edited by David Card and Steven Raphael.

National Poverty Center Series on Poverty and Public Policy.

Ruggles, Steven, J. Trent Alexander, Katie Genadek, Ronald Goeken, and Matthew

Schroeder, Matthew B. Sobek. 2010. “Integrated Public Use Microdata Series: Version

5.0 [Machine-Readable Database].” Minneapolis: University of Minnesota.

U.S. Immigration and Customs Enforcement (ICE). 2013. “Fact Sheet: Delegation of

Immigration Authority Section 287(g) Immigration and Nationality Act.”

—. 2015. "Fact Sheets 287g.” http://www.ice.gov/factsheets/287g.

Vaughan, Jessica M. 2013. “Deportation Numbers Unwrapped Raw Statistics Reveal the Real

Story of ICE Enforcement in Decline.” Center for Immigration Studies, no. October: 116.

Watson, Tara. 2013. “Enforcement and Immigrant Location Choice.” NBER Working Paper

Series 19626.

—. 2014. "Inside the Refrigerator: Immigration Enforcement and Chilling Effects in

Medicaid Participation.” American Economic Journal:Economic Policy 6 (3): 313-38.

Wong, Tom K. 2012. “287(g) and the Politics of Interior Immigration Control in the United

States: Explaining Local Cooperation with Federal Immigration Authorities,” Journal of Ethnic and Migration Studies, 38 (5): 737-756. 
Table 1: Summary Statistics

\begin{tabular}{|c|c|c|c|c|c|}
\hline Descriptive Statistic: & Mean & S.D. & Min & Max & Observations \\
\hline \multicolumn{6}{|l|}{ Panel A: Poverty and Income Related Measures } \\
\hline Poverty 100 & 0.32 & 0.47 & 0.00 & 1.00 & 150,141 \\
\hline Poverty 150 & 0.54 & 0.50 & 0.00 & 1.00 & 150,141 \\
\hline Log Family income & 10.09 & 0.84 & 0.00 & 13.78 & 147,049 \\
\hline Food Stamp & 0.22 & 0.42 & 0.00 & 1 & 150,414 \\
\hline \multicolumn{6}{|l|}{ Panel B: Other Regressors } \\
\hline Single Headed HH & 0.24 & 0.43 & 0.00 & 1.00 & 150,141 \\
\hline HH Head w/HS+ & 0.17 & 0.37 & 0.00 & 1.00 & 150,141 \\
\hline HH Head Does not Speak English & 0.47 & 0.50 & 0.00 & 1.00 & 150,141 \\
\hline Years in the U.S. for the HH Head & 13.37 & 9.57 & 0.00 & 65.00 & 150,141 \\
\hline Employed HH Head & 0.76 & 0.42 & 0.00 & 1.00 & 150,141 \\
\hline Age of the HH Head & 34.93 & 8.43 & 13.00 & 92.00 & 150,141 \\
\hline No. of Kids in the $\mathrm{HH}$ & 2.42 & 1.15 & 1.00 & 14.00 & 150,141 \\
\hline Unemployment Rate in CONSPUMA & 0.08 & 0.03 & 0.01 & 0.35 & 150,141 \\
\hline Share of Low-skilled in Agriculture in the 80s & 0.76 & 0.08 & 0.17 & 1 & 150,141 \\
\hline Share of Low-skilled in Services in the 80s & 0.78 & 0.06 & 0.46 & 0.96 & 150,141 \\
\hline Share Voting Republican in State in the 80s & 0.46 & 0.10 & 0.00 & 0.69 & 150,141 \\
\hline \multicolumn{6}{|l|}{ Panel C: Enforcement Index } \\
\hline Enforcement Index & 0.37 & 0.64 & 0.00 & 4.18 & 150,141 \\
\hline Local-level Enforcement & 0.19 & 0.27 & 0.00 & 1.48 & 150,141 \\
\hline State-level Enforcement & 0.19 & 0.52 & 0.00 & 3.00 & 150,141 \\
\hline Police-based Enforcement & 0.28 & 0.45 & 0.00 & 3.18 & 150,141 \\
\hline Employment-based Enforcement & 0.09 & 0.27 & 0.00 & 1.00 & 150,141 \\
\hline Enforcement Index Using Historical Residential Patterns & 0.05 & 0.13 & 0.00 & 2.09 & 150,141 \\
\hline
\end{tabular}

Notes: Sample: families with at least one U.S.-citizen child ranging between 0 and 18 years old with at least one undocumented parent. Data from ACS 2005-2011. 
Table 2: Probability of Living below the Poverty Line

\begin{tabular}{|c|c|c|c|c|}
\hline \multirow{2}{*}{ Independent Variables } & \multicolumn{4}{|c|}{ Model Specification } \\
\hline & 1 & 2 & 3 & 4 \\
\hline Enforcement Index & $\begin{array}{c}0.045^{* * *} \\
(0.008)\end{array}$ & $\begin{array}{c}0.019 * * * \\
(0.007)\end{array}$ & $\begin{array}{c}0.020^{* * *} \\
(0.005)\end{array}$ & $\begin{array}{c}0.021^{* *} \\
(0.010)\end{array}$ \\
\hline Single Headed HH & $\begin{array}{c}0.251^{* * *} \\
(0.005)\end{array}$ & $\begin{array}{c}0.246^{* * *} \\
(0.004)\end{array}$ & $\begin{array}{c}0.246^{* * *} \\
(0.004)\end{array}$ & $\begin{array}{c}0.246 * * * \\
(0.004)\end{array}$ \\
\hline HH Head w/HS+ & $\begin{array}{c}-0.083 * * * \\
(0.004)\end{array}$ & $\begin{array}{c}-0.084 * * * \\
(0.004)\end{array}$ & $\begin{array}{c}-0.084^{* * *} \\
(0.004)\end{array}$ & $\begin{array}{c}-0.084^{* * *} \\
(0.004)\end{array}$ \\
\hline HH Head Does Not Speak English & $\begin{array}{c}0.116^{* * *} \\
(0.004)\end{array}$ & $\begin{array}{c}0.111^{* * *} \\
(0.004)\end{array}$ & $\begin{array}{c}0.111^{* * * *} \\
(0.004)\end{array}$ & $\begin{array}{c}0.111^{* * *} \\
(0.004)\end{array}$ \\
\hline Years in the U.S. for the HH Head & $\begin{array}{c}-0.003 * * * \\
(0.000)\end{array}$ & $\begin{array}{c}-0.003^{* * *} \\
(0.000)\end{array}$ & $\begin{array}{c}-0.003^{* * *} \\
(0.000)\end{array}$ & $\begin{array}{c}-0.003^{* * *} \\
(0.000)\end{array}$ \\
\hline Employed HH Head & $\begin{array}{c}-0.219 * * * \\
(0.004)\end{array}$ & $\begin{array}{c}-0.210^{* * *} \\
(0.004)\end{array}$ & $\begin{array}{c}-0.210^{* * *} \\
(0.004)\end{array}$ & $\begin{array}{c}-0.210^{* * *} \\
(0.004)\end{array}$ \\
\hline Age of the HH Head & $\begin{array}{c}-0.005^{* * *} \\
(0.000)\end{array}$ & $\begin{array}{c}-0.005^{* * *} \\
(0.000)\end{array}$ & $\begin{array}{c}-0.005^{* * *} \\
(0.000)\end{array}$ & $\begin{array}{c}-0.005^{* * *} \\
(0.000)\end{array}$ \\
\hline No. of Kids in the $\mathrm{HH}$ & $\begin{array}{c}0.070 * * * \\
(0.002)\end{array}$ & $\begin{array}{c}0.069 * * * \\
(0.002)\end{array}$ & $\begin{array}{c}0.069 * * * \\
(0.002)\end{array}$ & $\begin{array}{c}0.069 * * * \\
(0.002)\end{array}$ \\
\hline Share Voting Republican in State & & & $\begin{array}{c}-0.184^{*} \\
(0.094)\end{array}$ & $\begin{array}{c}-0.064 \\
(0.118)\end{array}$ \\
\hline Unemployment Rate in CONSPUMA & & & $\begin{array}{c}0.094^{* * *} \\
(0.030)\end{array}$ & $\begin{array}{c}0.029 \\
(0.040)\end{array}$ \\
\hline Share of Low-skilled in Agriculture in the 80s & & & $\begin{array}{c}-0.008 \\
(0.015)\end{array}$ & $\begin{array}{c}0.030 * * * \\
(0.009)\end{array}$ \\
\hline Share of Low-skilled in Services in the 80s & & & $\begin{array}{l}-0.012 \\
(0.022)\end{array}$ & $\begin{array}{c}-0.251^{* * *} \\
(0.006)\end{array}$ \\
\hline Share of Low-skilled in Manufacturing in the 80s & & & $\begin{array}{c}-0.019 \\
(0.016)\end{array}$ & $\begin{array}{c}-0.461^{* * *} \\
(0.031)\end{array}$ \\
\hline Share of Low-skilled in Construction in the 80s & & & $\begin{array}{c}0.031 \\
(0.025)\end{array}$ & $\begin{array}{c}0.673 * * * \\
(0.032)\end{array}$ \\
\hline CONSPUMA FE & & Yes & Yes & Yes \\
\hline Year FE & & Yes & Yes & Yes \\
\hline CONSPUMA-specific Time Trend & & & & Yes \\
\hline Observations & 150,141 & 150,141 & 150,141 & 150,141 \\
\hline R-squared & 0.186 & 0.209 & 0.209 & 0.214 \\
\hline Dependent Variable Mean & & & & \\
\hline
\end{tabular}

Notes: Sample: families with at least one U.S.-citizen child ranging between 0 and 18 years old with at least one undocumented parent. Specification 1 includes only family characteristics. Specification 2 includes area and time fixed effects. Specification 3 adds aggregate CONSPUMA-time controls and Specification 4 further adds the CONSPUMA-specific time trend as in equation (2) in the text. Robust standard errors are in parentheses. ${ }^{* * *} \mathrm{p}<0.01$, ${ }^{* *} \mathrm{p}<0.05,{ }^{*} \mathrm{p}<0.1$. Standards errors are clustered at the CONSPUMA level. 
Table 3: Probability of Living below the Poverty Line - Families with Naturalized Parents

\begin{tabular}{|c|c|c|c|c|}
\hline \multirow{2}{*}{ Independent Variables } & \multicolumn{4}{|c|}{ Model Specification } \\
\hline & 1 & 2 & 3 & 4 \\
\hline Enforcement Index & $\begin{array}{l}0.010^{*} \\
(0.006)\end{array}$ & $\begin{array}{l}-0.001 \\
(0.007)\end{array}$ & $\begin{array}{c}0.001 \\
(0.007)\end{array}$ & $\begin{array}{l}-0.014 \\
(0.013)\end{array}$ \\
\hline Single Headed HH & $\begin{array}{c}0.183^{* * *} \\
(0.007)\end{array}$ & $\begin{array}{c}0.173^{* * *} \\
(0.006)\end{array}$ & $\begin{array}{c}0.173^{* * *} \\
(0.006)\end{array}$ & $\begin{array}{c}0.173 * * * \\
(0.006)\end{array}$ \\
\hline HH Head w/HS+ & $\begin{array}{c}-0.061^{* * *} \\
(0.005)\end{array}$ & $\begin{array}{c}-0.064^{* * *} \\
(0.006)\end{array}$ & $\begin{array}{c}-0.064^{* * *} \\
(0.005)\end{array}$ & $\begin{array}{c}-0.064 * * * \\
(0.006)\end{array}$ \\
\hline HH Head Does Not Speak English & $\begin{array}{c}0.085^{* * * *} \\
(0.007)\end{array}$ & $\begin{array}{c}0.079 * * * \\
(0.006)\end{array}$ & $\begin{array}{c}0.079 * * * \\
(0.006)\end{array}$ & $\begin{array}{c}0.078 * * * \\
(0.006)\end{array}$ \\
\hline Years in the U.S. for the HH Head & $\begin{array}{c}-0.002^{* * *} \\
(0.000)\end{array}$ & $\begin{array}{c}-0.001^{* * *} \\
(0.000)\end{array}$ & $\begin{array}{c}-0.001^{* * *} \\
(0.000)\end{array}$ & $\begin{array}{c}-0.001^{* * * *} \\
(0.000)\end{array}$ \\
\hline Employed HH Head & $\begin{array}{c}-0.231^{* * *} \\
(0.009)\end{array}$ & $\begin{array}{c}-0.225^{* * * *} \\
(0.008)\end{array}$ & $\begin{array}{c}-0.226^{* * *} \\
(0.008)\end{array}$ & $\begin{array}{c}-0.225^{* * * *} \\
(0.008)\end{array}$ \\
\hline Age of the HH Head & $\begin{array}{c}-0.003^{* * *} \\
(0.000)\end{array}$ & $\begin{array}{c}-0.003^{* * * *} \\
(0.000)\end{array}$ & $\begin{array}{c}-0.003^{* * *} \\
(0.000)\end{array}$ & $\begin{array}{c}-0.003^{* * * *} \\
(0.000)\end{array}$ \\
\hline No. of Kids in the $\mathrm{HH}$ & & $\begin{array}{c}0.037 * * * \\
(0.003)\end{array}$ & $\begin{array}{c}0.037 * * * \\
(0.003)\end{array}$ & $\begin{array}{c}0.037 * * * \\
(0.003)\end{array}$ \\
\hline Share Voting Republican in State & & & $\begin{array}{l}-0.040 \\
(0.124)\end{array}$ & $\begin{array}{c}0.105 \\
(0.153)\end{array}$ \\
\hline Unemployment Rate in CONSPUMA & & & $\begin{array}{c}0.049 \\
(0.031)\end{array}$ & $\begin{array}{l}0.099 * \\
(0.058)\end{array}$ \\
\hline Share of Low-skilled in Agriculture & & & $\begin{array}{c}0.003 \\
(0.014)\end{array}$ & $\begin{array}{c}-0.195^{* * * *} \\
(0.009)\end{array}$ \\
\hline Share of Low-skilled in Services & & & $\begin{array}{l}-0.028 \\
(0.034)\end{array}$ & $\begin{array}{c}-0.368 * * * \\
(0.018)\end{array}$ \\
\hline Share of Low-skilled in Manufacturing & & & $\begin{array}{l}-0.006 \\
(0.019)\end{array}$ & $\begin{array}{c}-1.361^{* * *} \\
(0.063)\end{array}$ \\
\hline Share of Low-skilled in Construction & & & $\begin{array}{c}0.031 \\
(0.030)\end{array}$ & $\begin{array}{c}1.874 * * * \\
(0.080)\end{array}$ \\
\hline $\begin{array}{l}\text { CONSPUMA FE } \\
\text { Year FE } \\
\text { CONSPUMA-specific Time Trend }\end{array}$ & & $\begin{array}{l}\text { Yes } \\
\text { Yes }\end{array}$ & $\begin{array}{l}\text { Yes } \\
\text { Yes }\end{array}$ & $\begin{array}{l}\text { Yes } \\
\text { Yes } \\
\text { Yes }\end{array}$ \\
\hline $\begin{array}{l}\text { Observations } \\
\text { R-squared }\end{array}$ & $\begin{array}{c}48,250 \\
0.186\end{array}$ & $\begin{array}{c}48,250 \\
0.209\end{array}$ & $\begin{array}{c}48,250 \\
0.209\end{array}$ & $\begin{array}{c}48,250 \\
0.214\end{array}$ \\
\hline Dependent Variable Mean: & & & & \\
\hline
\end{tabular}

Notes: Sample: families with at least one U.S.-citizen child ranging between 0 and 18 years old with naturalized parent. Specification 1 includes only family characteristics. Specification 2 includes area and time fixed effects. Specification 3 adds aggregate CONSPUMA-time controls and Specification 4 further adds the CONSPUMA-specific time trend as in equation (2) in the text. Robust standard errors are in parentheses. ${ }^{* * *} \mathrm{p}<0.01,{ }^{* *} \mathrm{p}<0.05,{ }^{*} \mathrm{p}<0.1$. Standards errors are clustered at the CONSPUMA level. 
Table 4: Assessing the Existence of Parallel Poverty Pre-trends

\begin{tabular}{|c|c|c|c|c|}
\hline Model Specification: & 1 & 2 & 3 & 4 \\
\hline \multicolumn{5}{|l|}{ Elapsed time* LU parents } \\
\hline \multirow[t]{2}{*}{$-4 * \mathrm{LU}$} & 0.011 & 0.008 & 0.007 & 0.005 \\
\hline & $(0.012)$ & $(0.012)$ & $(0.012)$ & $(0.012)$ \\
\hline \multirow[t]{2}{*}{$-3 * \mathrm{LU}$} & 0.014 & 0.012 & 0.011 & 0.011 \\
\hline & $(0.010)$ & $(0.009)$ & $(0.009)$ & $(0.009)$ \\
\hline \multirow[t]{2}{*}{$-2 * L U$} & $0.016^{*}$ & 0.013 & 0.012 & 0.012 \\
\hline & $(0.009)$ & $(0.009)$ & $(0.009)$ & $(0.009)$ \\
\hline \multirow[t]{2}{*}{$-1 * \mathrm{LU}$} & 0.016 & 0.013 & 0.013 & 0.012 \\
\hline & $(0.011)$ & $(0.010)$ & $(0.010)$ & $(0.010)$ \\
\hline \multirow[t]{2}{*}{$0 * \mathrm{LU}$} & $0.034 * * *$ & $0.031 * * *$ & $0.031 * * *$ & $0.031 * * *$ \\
\hline & $(0.010)$ & $(0.010)$ & $(0.010)$ & $(0.010)$ \\
\hline \multirow[t]{2}{*}{$1 * \mathrm{LU}$} & $0.041 * * *$ & $0.034 * * *$ & $0.034 * * *$ & $0.034 * * *$ \\
\hline & $(0.012)$ & $(0.011)$ & $(0.012)$ & $(0.012)$ \\
\hline \multirow[t]{2}{*}{$2 * \mathrm{LU}$} & $0.046^{* * *}$ & $0.033^{*} *$ & $0.033^{* *}$ & $0.035 * * *$ \\
\hline & $(0.013)$ & $(0.013)$ & $(0.013)$ & $(0.013)$ \\
\hline \multirow[t]{2}{*}{$3 * \mathrm{LU}$} & $0.047 * * *$ & $0.032 * *$ & $0.032 * *$ & $0.030 * *$ \\
\hline & $(0.012)$ & $(0.013)$ & $(0.013)$ & $(0.013)$ \\
\hline \multirow[t]{2}{*}{$4 * \mathrm{LU}$} & $0.053 * * *$ & $0.043^{* *}$ & $0.043^{* *}$ & $0.043 * *$ \\
\hline & $(0.016)$ & $(0.020)$ & $(0.020)$ & $(0.020)$ \\
\hline CONSPUMA FE & & Yes & Yes & Yes \\
\hline Year FE & & Yes & Yes & Yes \\
\hline CONSPUMA-specific Time Trend & & & & Yes \\
\hline Observations & 198,393 & 198,393 & 198,393 & 198,393 \\
\hline R-squared & 0.200 & 0.221 & 0.221 & 0.225 \\
\hline
\end{tabular}

Notes: Sample: families with at least one U.S.-citizen child ranging between 0 and 18 years old with at least one undocumented parent. Specification 1 includes only family characteristics. Specification 2 includes area and time fixed effects. Specification 3 adds aggregate CONSPUMA-time controls and Specification 4 further adds CONSPUMA-specific time trends. All regressions include a constant term, as well as the other regressors included in equation (3) in the text. Robust standard errors are in parentheses. ${ }^{* * *} \mathrm{p}<0.01,{ }^{* *} \mathrm{p}<0.05,{ }^{*} \mathrm{p}<0.1$. Standards errors are clustered at the CONSPUMA level. 
Table 5: First Year the Enforcement Immigration Index Turns Positive

\begin{tabular}{|c|c|c|c|c|}
\hline Model Specification & 1 & 2 & 3 & 4 \\
\hline Share of HHs Living below the Poverty Line & $\begin{array}{c}11.008 \\
(42.112)\end{array}$ & $\begin{array}{c}-3.770 \\
(27.146)\end{array}$ & $\begin{array}{c}-44.772 \\
(54.269)\end{array}$ & $\begin{array}{l}-39.601 \\
(42.740)\end{array}$ \\
\hline Share of Single Headed HHs & & $\begin{array}{c}1.191 \\
(43.852)\end{array}$ & $\begin{array}{l}-19.499 \\
(28.369)\end{array}$ & $\begin{array}{l}-27.679 \\
(35.347)\end{array}$ \\
\hline Share of HH Heads with a HS Education or More & & $\begin{array}{c}37.219 \\
(66.843)\end{array}$ & $\begin{array}{c}25.073 \\
(35.953)\end{array}$ & $\begin{array}{c}12.619 \\
(25.638)\end{array}$ \\
\hline Share of HH Heads without a HS Diploma & & $\begin{array}{c}6.257 \\
(30.791)\end{array}$ & $\begin{array}{c}21.536 \\
(22.799)\end{array}$ & $\begin{array}{c}37.538 \\
(41.942)\end{array}$ \\
\hline Share of non-English proficient HH heads & & $\begin{array}{c}29.352 \\
(52.684)\end{array}$ & $\begin{array}{c}-4.494 \\
(25.492)\end{array}$ & $\begin{array}{l}-20.236 \\
(44.669)\end{array}$ \\
\hline Average Number of Years in the U.S. & & $\begin{array}{l}-1.476 \\
(2.088)\end{array}$ & $\begin{array}{c}1.417 \\
(2.099)\end{array}$ & $\begin{array}{c}0.417 \\
(1.191)\end{array}$ \\
\hline Share of Working HH Heads & & $\begin{array}{l}-31.057 \\
(51.467)\end{array}$ & $\begin{array}{c}28.959 \\
(33.506)\end{array}$ & $\begin{array}{c}25.438 \\
(29.659)\end{array}$ \\
\hline Average Age of HH Head & & $\begin{array}{l}-0.082 \\
(2.358)\end{array}$ & $\begin{array}{l}-3.418 \\
(4.194)\end{array}$ & $\begin{array}{l}-1.250 \\
(2.636)\end{array}$ \\
\hline Average number of kids per $\mathrm{HH}$ & & $\begin{array}{c}9.129 \\
(20.647)\end{array}$ & $\begin{array}{c}-5.089 \\
(21.922)\end{array}$ & $\begin{array}{l}-11.278 \\
(21.094)\end{array}$ \\
\hline Average Unemployment Rate in CONSPUMA & & & & $\begin{array}{l}-767.924 \\
(852.855)\end{array}$ \\
\hline Share of Low-skilled in Agriculture & & & & $\begin{array}{l}-20.172 \\
(64.006)\end{array}$ \\
\hline Share of Low-skilled in Services & & & & $\begin{array}{c}649.001 \\
(752.896)\end{array}$ \\
\hline Share of Low-skilled in Manufacturing & & & & $\begin{array}{l}-178.033 \\
(189.593)\end{array}$ \\
\hline Share of Low-skilled in Construction & & & & $\begin{array}{c}-365.951 \\
(374.871)\end{array}$ \\
\hline Share Voting Republican in State & & & & $\begin{array}{c}58.742 \\
(149.643)\end{array}$ \\
\hline Constant & $\begin{array}{c}1,981.402^{* * *} \\
(19.085)\end{array}$ & $\begin{array}{c}1,988.301 * * * \\
(61.081)\end{array}$ & $\begin{array}{c}2,072.350 * * * \\
\quad(122.300)\end{array}$ & $\begin{array}{c}2,000.851 * * * \\
\quad(161.744)\end{array}$ \\
\hline MSA FE & No & No & Yes & Yes \\
\hline $\begin{array}{l}\text { Observations } \\
\text { R-squared }\end{array}$ & $\begin{array}{c}478 \\
0.002\end{array}$ & $\begin{array}{c}478 \\
0.003\end{array}$ & $\begin{array}{c}478 \\
0.593\end{array}$ & $\begin{array}{c}478 \\
0.609\end{array}$ \\
\hline
\end{tabular}

Notes: Sample: All CONSPUMAs. Robust standard errors are in parentheses and clustered at the Metropolitan Statistical Area (MSA) level. ${ }^{* * *} \mathrm{p}<0.01,{ }^{* *} \mathrm{p}<0.05,{ }^{*} \mathrm{p}<0.1$. 
Table 6: Probability of Living below the Poverty Line -

Addressing the Non-random Location of Immigrants

\begin{tabular}{|c|c|c|c|c|}
\hline \multirow{2}{*}{ Regressors } & \multicolumn{4}{|c|}{ Model Specification } \\
\hline & 1 & 2 & 3 & 4 \\
\hline Enforcement Index & $\begin{array}{c}0.052^{* * *} \\
(0.012)\end{array}$ & $\begin{array}{c}0.026^{* * *} \\
(0.010)\end{array}$ & $\begin{array}{c}0.026^{* * *} \\
(0.009)\end{array}$ & $\begin{array}{c}0.101^{* * *} \\
(0.020)\end{array}$ \\
\hline Single Headed HH & $\begin{array}{c}0.251^{* * *} \\
(0.005)\end{array}$ & $\begin{array}{c}0.246^{* * *} \\
(0.004)\end{array}$ & $\begin{array}{c}0.246 * * * \\
(0.004)\end{array}$ & $\begin{array}{c}0.246^{* * *} \\
(0.004)\end{array}$ \\
\hline HH Head w/HS+ & $\begin{array}{c}-0.083^{* * *} \\
(0.004)\end{array}$ & $\begin{array}{c}-0.084^{* * *} \\
(0.004)\end{array}$ & $\begin{array}{c}-0.084^{* * *} \\
(0.004)\end{array}$ & $\begin{array}{c}-0.084 * * * \\
(0.004)\end{array}$ \\
\hline HH Head Does Not Speak English & $\begin{array}{c}0.116^{* * *} \\
(0.004)\end{array}$ & $\begin{array}{c}0.111^{* * *} \\
(0.004)\end{array}$ & $\begin{array}{c}0.111^{* * *} \\
(0.004)\end{array}$ & $\begin{array}{c}0.111^{* * *} \\
(0.004)\end{array}$ \\
\hline Years in the U.S. for the HH Head & $\begin{array}{c}-0.003^{* * *} \\
(0.000)\end{array}$ & $\begin{array}{c}-0.003^{* * * *} \\
(0.000)\end{array}$ & $\begin{array}{c}-0.003^{* * *} \\
(0.000)\end{array}$ & $\begin{array}{c}-0.003^{* * *} \\
(0.000)\end{array}$ \\
\hline Employed HH Head & $\begin{array}{c}-0.219 * * * \\
(0.004)\end{array}$ & $\begin{array}{c}-0.210^{* * *} \\
(0.004)\end{array}$ & $\begin{array}{c}-0.210^{* * *} \\
(0.004)\end{array}$ & $\begin{array}{c}-0.210 * * * \\
(0.004)\end{array}$ \\
\hline Age of the HH Head & $\begin{array}{c}-0.005^{* * *} \\
(0.000)\end{array}$ & $\begin{array}{c}-0.005^{* * *} \\
(0.000)\end{array}$ & $\begin{array}{c}-0.005^{* * *} \\
(0.000)\end{array}$ & $\begin{array}{c}-0.005^{* * *} \\
(0.000)\end{array}$ \\
\hline No. of Kids in the $\mathrm{HH}$ & $\begin{array}{c}0.070^{* * *} \\
(0.002)\end{array}$ & $\begin{array}{c}0.069 * * * \\
(0.002)\end{array}$ & $\begin{array}{c}0.069 * * * \\
(0.002)\end{array}$ & $\begin{array}{c}0.069 * * * \\
(0.002)\end{array}$ \\
\hline Share Voting Republican in State & & & $\begin{array}{l}-0.183^{*} \\
(0.095)\end{array}$ & $\begin{array}{c}-0.102 \\
(0.127)\end{array}$ \\
\hline Unemployment Rate in CONSPUMA & & & $\begin{array}{c}0.096 * * * \\
(0.030)\end{array}$ & $\begin{array}{c}0.041 \\
(0.045)\end{array}$ \\
\hline Share of Low-skilled in Agriculture in the 80s & & & $\begin{array}{c}-0.008 \\
(0.015)\end{array}$ & $\begin{array}{l}0.017^{*} \\
(0.010)\end{array}$ \\
\hline Share of Low-skilled in Services in the 80s & & & $\begin{array}{l}-0.011 \\
(0.023)\end{array}$ & $\begin{array}{c}-0.257 * * * \\
(0.007)\end{array}$ \\
\hline Share of Low-skilled in Manufacturing in the 80s & & & $\begin{array}{c}-0.018 \\
(0.016)\end{array}$ & $\begin{array}{c}-0.462 * * * \\
(0.037)\end{array}$ \\
\hline Share of Low-skilled in Construction in the 80s & & & $\begin{array}{c}0.030 \\
(0.025)\end{array}$ & $\begin{array}{c}0.693 * * * \\
(0.037)\end{array}$ \\
\hline CONSPUMA FE & & Yes & Yes & Yes \\
\hline Year FE & & Yes & Yes & Yes \\
\hline CONSPUMA-specific Time Trend & & & & Yes \\
\hline Observations & 150,141 & 150,141 & 150,141 & 150,141 \\
\hline R-squared & 0.186 & 0.209 & 0.209 & 0.214 \\
\hline Dependent Variable Mean & & & .32 & \\
\hline
\end{tabular}

Notes: Sample: families with at least one U.S.-citizen child ranging between 0 and 18 years old with at least one undocumented parent. Specification 1 includes only family characteristics. Specification 2 includes area and time fixed effects. Specification 3 adds aggregate CONSPUMA-time controls and Specification 4 further adds CONSPUMAspecific time trends. All regressions include a constant term. Robust standard errors are in parentheses and clustered at the CONSPUMA level. ${ }^{* * *} \mathrm{p}<0.01,{ }^{* *} \mathrm{p}<0.05$, and ${ }^{*} \mathrm{p}<0.1$. 
Table 7: Robustness Checks using Alternative Dependent Variables

\begin{tabular}{|c|c|c|c|c|c|c|c|c|}
\hline \multirow{2}{*}{ Model Specification } & \multicolumn{4}{|c|}{ Households with LU parents } & \multicolumn{4}{|c|}{ Households with Naturalized Parents } \\
\hline & 1 & 2 & 3 & 4 & 1 & 2 & 3 & 4 \\
\hline \multicolumn{9}{|c|}{ Panel A: HH Income is No more than 1.5 Times the Poverty Threshold } \\
\hline Enforcement Index & $\begin{array}{c}0.048^{* * *} \\
(0.010)\end{array}$ & $\begin{array}{l}0.012 * \\
(0.007)\end{array}$ & $\begin{array}{c}0.013 * * \\
(0.005)\end{array}$ & $\begin{array}{c}0.021^{* *} \\
(0.009)\end{array}$ & $\begin{array}{c}0.018^{* * *} \\
(0.007)\end{array}$ & $\begin{array}{c}-0.007 \\
(0.006)\end{array}$ & $\begin{array}{c}-0.004 \\
(0.005)\end{array}$ & $\begin{array}{l}-0.017 \\
(0.012)\end{array}$ \\
\hline $\begin{array}{l}\text { Observations } \\
\text { R-squared }\end{array}$ & $\begin{array}{c}150,141 \\
0.211\end{array}$ & $\begin{array}{c}150,141 \\
0.241\end{array}$ & $\begin{array}{c}150,141 \\
0.241\end{array}$ & $\begin{array}{c}150,141 \\
0.251\end{array}$ & $\begin{array}{c}48,250 \\
0.211\end{array}$ & $\begin{array}{c}48,250 \\
0.241\end{array}$ & $\begin{array}{c}48,250 \\
0.241\end{array}$ & $\begin{array}{c}48,250 \\
0.251\end{array}$ \\
\hline Dependent Variable Mean & \multicolumn{4}{|c|}{0.58} & \multicolumn{4}{|c|}{0.28} \\
\hline \multicolumn{9}{|l|}{ Panel B: Log (Real HH Income) } \\
\hline Enforcement Index & $\begin{array}{c}-0.084^{* * *} \\
(0.017)\end{array}$ & $\begin{array}{c}-0.029 * * * \\
(0.011)\end{array}$ & $\begin{array}{c}-0.031^{* * *} \\
(0.008)\end{array}$ & $\begin{array}{c}-0.029 * * \\
(0.013)\end{array}$ & $\begin{array}{c}-0.041 * * * \\
(0.013)\end{array}$ & $\begin{array}{c}0.009 \\
(0.013)\end{array}$ & $\begin{array}{c}0.002 \\
(0.012)\end{array}$ & $\begin{array}{c}0.023 \\
(0.022)\end{array}$ \\
\hline $\begin{array}{l}\text { Observations } \\
\text { R-squared }\end{array}$ & $\begin{array}{c}147,049 \\
0.241\end{array}$ & $\begin{array}{c}147,049 \\
0.272\end{array}$ & $\begin{array}{c}147,049 \\
0.272\end{array}$ & $\begin{array}{c}147,049 \\
0.277\end{array}$ & $\begin{array}{c}48,628 \\
0.324\end{array}$ & $\begin{array}{c}48,628 \\
0.359\end{array}$ & $\begin{array}{c}48,628 \\
0.360\end{array}$ & $\begin{array}{c}48,628 \\
0.370\end{array}$ \\
\hline Dependent Variable Mean & \multicolumn{4}{|c|}{10.09} & \multicolumn{4}{|c|}{10.53} \\
\hline \multicolumn{9}{|l|}{ Panel C: Food Stamp Receipt } \\
\hline Enforcement Index & $\begin{array}{c}0.043^{* * *} \\
(0.009)\end{array}$ & $\begin{array}{c}0.019 * * * \\
(0.006)\end{array}$ & $\begin{array}{c}0.021^{* * *} \\
(0.005)\end{array}$ & $\begin{array}{c}0.023^{* *} \\
(0.009)\end{array}$ & $\begin{array}{c}0.017 * * * \\
(0.006)\end{array}$ & $\begin{array}{l}-0.006 \\
(0.006)\end{array}$ & $\begin{array}{c}-0.003 \\
(0.005)\end{array}$ & $\begin{array}{l}-0.018 \\
(0.012)\end{array}$ \\
\hline $\begin{array}{l}\text { Observations } \\
\text { R-squared }\end{array}$ & $\begin{array}{c}150,141 \\
0.105\end{array}$ & $\begin{array}{c}150,141 \\
0.174\end{array}$ & $\begin{array}{c}150,141 \\
0.175\end{array}$ & $\begin{array}{c}150,141 \\
0.105\end{array}$ & $\begin{array}{c}48,250 \\
0.211\end{array}$ & $\begin{array}{c}48,250 \\
0.241\end{array}$ & $\begin{array}{c}48,250 \\
0.242\end{array}$ & $\begin{array}{c}48,250 \\
0.251\end{array}$ \\
\hline Dependent Variable Mean & \multicolumn{4}{|c|}{0.22} & \multicolumn{4}{|c|}{0.13} \\
\hline $\begin{array}{l}\text { CONSPUMA FE } \\
\text { Year FE } \\
\text { CONSPUMA-specific Time Trend }\end{array}$ & & $\begin{array}{l}\text { Yes } \\
\text { Yes }\end{array}$ & $\begin{array}{l}\text { Yes } \\
\text { Yes }\end{array}$ & $\begin{array}{l}\text { Yes } \\
\text { Yes } \\
\text { Yes }\end{array}$ & & $\begin{array}{l}\text { Yes } \\
\text { Yes }\end{array}$ & $\begin{array}{l}\text { Yes } \\
\text { Yes }\end{array}$ & $\begin{array}{l}\text { Yes } \\
\text { Yes } \\
\text { Yes }\end{array}$ \\
\hline
\end{tabular}

Notes: Sample: families with naturalized or undocumented parents and children between 0 and 18 years old. Specification 1 includes only family characteristics. Specification 2 includes area and time fixed effects. Specification 3 adds aggregate CONSPUMA-time controls and Specification 4 adds CONSPUMA-specific time trends. Robust standard errors in parentheses. ${ }^{* * *} \mathrm{p}<0.01,{ }^{* *} \mathrm{p}<0.05$, ${ }^{*} \mathrm{p}<0.1$. Standards errors are clustered at the CONSPUMA level. 
Table 8: Probability of Living below the Poverty Line-Alternative Samples

\begin{tabular}{|c|c|c|c|c|}
\hline Model Specification & 1 & 2 & 3 & 4 \\
\hline \multicolumn{5}{|c|}{ Panel A: Likely Unauthorized Parents with More than 5 Years of U.S. Residency } \\
\hline Enforcement Index & $\begin{array}{c}0.050 * * * \\
(0.009)\end{array}$ & $\begin{array}{c}0.022^{* * *} \\
(0.006)\end{array}$ & $\begin{array}{c}0.023 * * * \\
(0.005)\end{array}$ & $\begin{array}{c}0.028 * * \\
(0.012)\end{array}$ \\
\hline Observations & 118,529 & 118,529 & 118,529 & 118,529 \\
\hline R-squared & 0.182 & 0.206 & 0.206 & 0.212 \\
\hline Dependent Variable Mean & \multicolumn{4}{|c|}{0.30} \\
\hline \multicolumn{5}{|l|}{ Panel B: HH Lacks HS Diploma } \\
\hline Enforcement Index & $\begin{array}{c}0.054^{* * *} \\
(0.011)\end{array}$ & $\begin{array}{c}0.025^{* * *} \\
(0.007)\end{array}$ & $\begin{array}{c}0.025^{* * *} \\
(0.007)\end{array}$ & $\begin{array}{c}0.029 * * \\
(0.013)\end{array}$ \\
\hline Observations & 75,091 & 75,091 & 75,091 & 75,091 \\
\hline R-squared & 0.158 & 0.189 & 0.189 & 0.198 \\
\hline Dependent Variable Mean & \multicolumn{4}{|c|}{0.38} \\
\hline \multicolumn{5}{|c|}{ Panel C: HH Head is Less than 45 Years of Age } \\
\hline Enforcement Index & $\begin{array}{c}0.045^{* * *} \\
(0.008)\end{array}$ & $\begin{array}{c}0.020 * * * \\
(0.007)\end{array}$ & $\begin{array}{c}0.021^{* * *} \\
(0.006)\end{array}$ & $\begin{array}{c}0.021^{* *} \\
(0.011)\end{array}$ \\
\hline Observations & 130,275 & 130,275 & 130,275 & 130,275 \\
\hline R-squared & 0.193 & 0.217 & 0.217 & 0.221 \\
\hline Dependent Variable Mean & \multicolumn{4}{|c|}{0.32} \\
\hline CONSPUMA FE & & Yes & Yes & Yes \\
\hline Year FE & & Yes & Yes & Yes \\
\hline CONSPUMA-specific Time Trend & & & & Yes \\
\hline
\end{tabular}

Notes: Specification 1 includes only family characteristics. Specification 2 includes area and time fixed effects. Specification 3 adds aggregate CONSPUMA-time controls and Specification 4 further adds CONSPUMA-specific time trends. All regressions include a constant term. Robust standard errors in parentheses. ${ }^{* * *} \mathrm{p}<0.01,{ }^{* *} \mathrm{p}<0.05,{ }^{*} \mathrm{p}<0.1$. Standards errors are clustered at the CONSPUMA level. 
Table 9: Probability of Living below the Poverty Line

\begin{tabular}{lcccc}
\hline \multirow{2}{*}{ Key Repressors } & \multicolumn{3}{c}{ Model Specification } \\
\cline { 2 - 5 } & $\mathbf{1}$ & $\mathbf{2}$ & $\mathbf{3}$ & $\mathbf{4}$ \\
\hline Panel A: By Geographic Scope of the Enforcement Measure & & \\
\hline \multirow{2}{*}{ Local-level Enforcement } & $0.081^{* * *}$ & $0.024^{*}$ & $0.026^{* *}$ & $0.030^{* *}$ \\
& $(0.016)$ & $(0.014)$ & $(0.011)$ & $(0.015)$ \\
State-level Enforcement & $0.033^{* * *}$ & $0.017^{* *}$ & $0.018^{* * *}$ & 0.017 \\
& $(0.010)$ & $(0.007)$ & $(0.006)$ & $(0.011)$ \\
\hline Panel B: By Type of Enforcement Measure & & & & \\
\hline \multirow{2}{*}{ Policed enforcement } & $0.046^{* * *}$ & $0.015^{*}$ & $0.018^{* *}$ & $0.022^{* * *}$ \\
& $(0.014)$ & $(0.008)$ & $(0.007)$ & $(0.009)$ \\
Employment enforcement & $0.045^{* * *}$ & $0.025^{* *}$ & $0.023^{* *}$ & 0.019 \\
& $(0.013)$ & $(0.012)$ & $(0.011)$ & $(0.024)$ \\
Observations & 150,141 & 150,141 & 150,141 & 150,141 \\
R-squared & 0.187 & 0.209 & 0.209 & 0.214 \\
CONSPUMA FE & & Yes & Yes & Yes \\
Year FE & & Yes & Yes & Yes \\
CONSPUMA-specific Time Trend & & & & Yes \\
Dependent Variable Mean & & & 0.32 &
\end{tabular}

Notes: Sample: families with at least one U.S.-citizen child ranging between 0 and 18 years old with at least one undocumented parent. Specification 1 includes only family characteristics. Specification 2 includes area and time fixed effects. Specification 3 adds aggregate CONSPUMAtime controls and Specification 4 add CONSPUMA-specific time trends. Robust standard errors in parentheses. ${ }^{* * *} \mathrm{p}<0.01,{ }^{* *} \mathrm{p}<0.05,{ }^{*} \mathrm{p}<0.1$. Standards errors are clustered at the CONSPUMA level. 
Figure 1: Geographic Variation in Enforcement over Time

Panel A: Year 2004

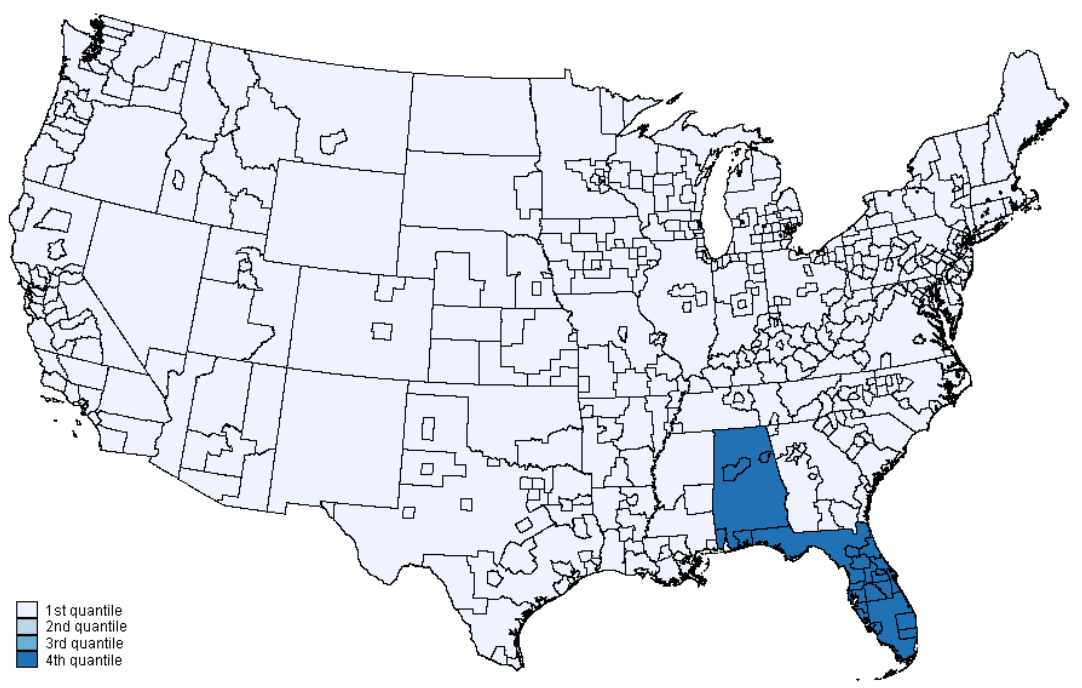

Panel B: Year 2007

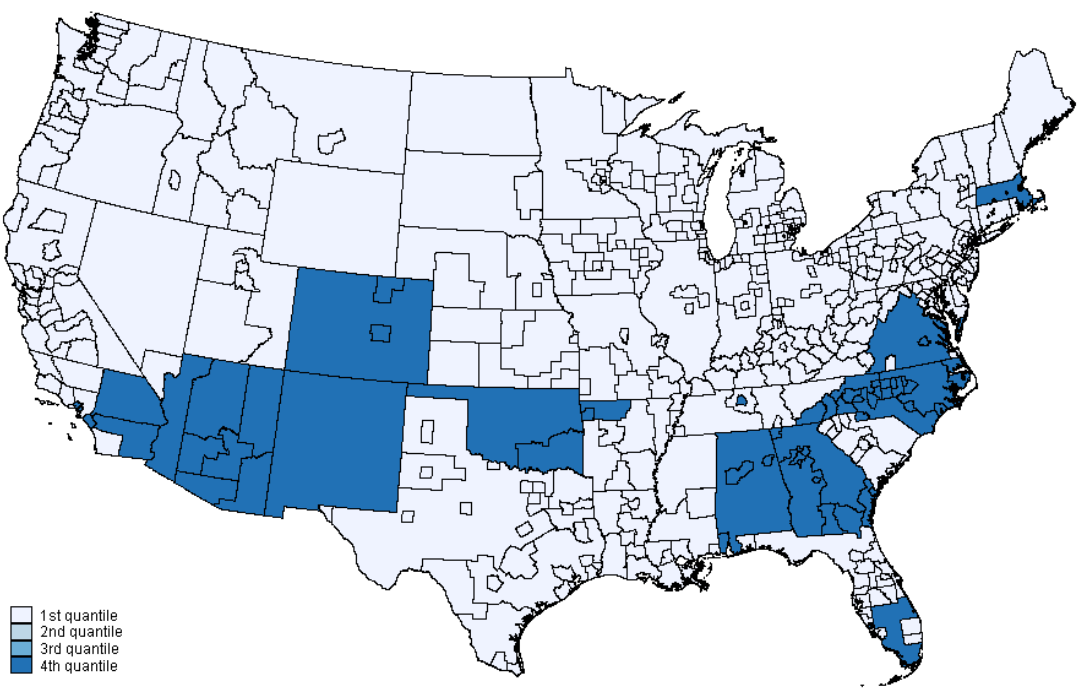


Panel C: Year 2010

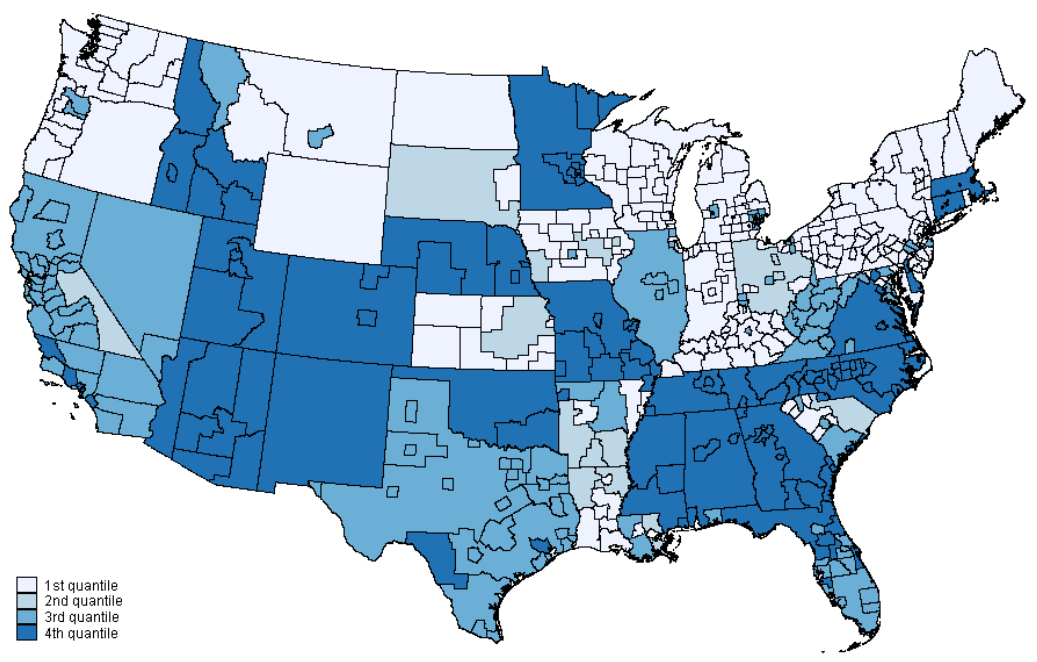

Notes: Figure 1 shows the roll out of immigration enforcement measures between 2004 and 2010. Lighter colours correspond to lower levels of enforcement (captured by the interior immigration enforcement index $E I_{c, t}$ ) in CONSPUMA $c$ in year $t$. 


\section{Appendix A: Interior Immigration Enforcement}

This appendix provides a brief history of interior enforcement immigration legislation, and Table A.2 describes the main features of each piece of legislation.

- Police-Based Enforcement: The 287(g) agreements were enacted as a section of the Illegal Immigration Reform and Immigrant Responsibility Act of 1996 (IIRIRA), and was the only program which permitted state and local law enforcement officials to enforce federal immigration law directly. State and local (at the country, town, or city level) agencies were able to enforce civil immigration law by signing an agreement (so-called Memorandum of Agreement or MOA) with the U.S. Immigration and Customs Enforcement (ICE). The first 287(g) program was signed by the Department of Law Enforcement in the state of Florida and ICE in 2002, and the number of 287 (g) agreements grew quickly after that.

In 2012, the Department of Homeland Security (DHS) ended the signing of 287(g) agreements due to the increased number of complaints about racial profiling, their high implementation cost, and accusations that the agreements were used as a political tool that interfered with protecting and serving communities (see Amuedo-Dorantes and Puttitanun, 2014). In place of the 287(g) agreements, DHS promoted participation in its Secure Communities program. The funding for the Secure Communities program grew considerably over the period 2008 to 2011, which allowed for the speedy implementation of the program and for the massive increase in the numbers of individuals screened by ICE. In 2014, DHS ended the Secure Communities program.

Omnibus immigration laws were enacted and passed by a number of states, starting with Arizona in 2010. While the content of each omnibus immigration law differs, they typically include the well-known "show me your papers' clause", which enables the police to request proper identification documentation during a lawful stop. Governor Jan Brewer signed the "Support Our Law Enforcement and Safe Neighbourhoods Act" (SB 1070) into law on April 23, 2010. Once of the tougher immigration laws, SB 1070 considers a misdemeanour crime if aliens over 14 years of age residing in the United States for longer than 30 days are not properly registered or do not have their documentation with them at all times. Additionally, it makes state and local enforcement officers responsible for determining an individual's immigration status during a "lawful stop, detention or arrest" if there is a suspicion that the person might be an undocumented immigrant. The Act bans state or local officials, as well as agencies, from restricting the enforcement of federal immigration laws, establishes penalties on those harbouring, hiring and transporting undocumented immigrants, and allows legal residents to sue state or localities that limit the implementation of immigration enforcement. One day before these laws were to become effective on July, 2010, the U.S. Department of Justice argued that SB 1070 was unconstitutional and filed a lawsuit asking for an injunction against it. The law's most questionable provisions were blocked. By the end of the same month when it was signed into law, HB 2162 was approved to rectify SB 2010 and make sure that law enforcement cannot consider race, color or national origin when implementing the provisions of the original law, except as permitted by the U.S. or Arizona Constitution.

- Employment-based Enforcement: E-verify is a voluntary program that allows employers to screen newly hired workers for work eligibility. Enrolment in E-Verify grew fairly quickly from 1,064 in 2001 to 482,692 in 2014 (Department of Homeland, 2014). 
Table A.1: Description of Enforcement Laws

\begin{tabular}{|c|c|c|c|c|c|c|c|c|}
\hline $\begin{array}{c}\text { Nature of the } \\
\text { Laws }\end{array}$ & Law & Years & $\begin{array}{c}\text { Area of } \\
\text { application }\end{array}$ & Objective & $\begin{array}{c}\text { Who is } \\
\text { applying it? }\end{array}$ & $\begin{array}{l}\text { Geographic } \\
\text { Coverage }\end{array}$ & Signed by & Types \\
\hline \multirow[t]{3}{*}{$\begin{array}{c}\text { Police-Base } \\
\text { Measures }\end{array}$} & 287(g) & $2002-$ & Street/Jail & $\begin{array}{l}\text { Make } \\
\text { communities } \\
\text { safer by the } \\
\text { identification } \\
\text { and removal } \\
\text { of serious } \\
\text { criminals }\end{array}$ & $\begin{array}{c}\text { State and } \\
\text { local law } \\
\text { enforcement } \\
\text { entities }\end{array}$ & $\begin{array}{l}\text { State and } \\
\text { Local }\end{array}$ & $\begin{array}{c}\text { State and local } \\
\text { enforcement } \\
\text { entities signed } \\
\text { a contract } \\
\text { (Memorandum } \\
\text { of Agreement } \\
\text {-MOA) with } \\
\text { the U.S. } \\
\text { Immigration } \\
\text { and Customs } \\
\text { Enforcement } \\
\text { (ICE) }\end{array}$ & $\begin{array}{l}\text { Task Force: allows local } \\
\text { and state officers interrogate } \\
\text { and arrest noncitizens during } \\
\text { their regular duties on law } \\
\text { enforcement operations. } \\
\text { Jail enforcement permits } \\
\text { local officers to question } \\
\text { immigrant who have been } \\
\text { arrested on state and local } \\
\text { charges about their } \\
\text { immigration status. } \\
\text { Hybrid model: which allow } \\
\text { participate in both types of } \\
\text { programs. }\end{array}$ \\
\hline & SC & $\begin{array}{l}2009- \\
2014\end{array}$ & $\begin{array}{l}\text { Nation's } \\
\text { jail and } \\
\text { prisons }\end{array}$ & $\begin{array}{c}\text { Identify } \\
\text { noncitizens } \\
\text { who have } \\
\text { committed } \\
\text { serious crime } \\
\text { using } \\
\text { biometric } \\
\text { information }\end{array}$ & Police & Local & Jurisdictions & \\
\hline & $\begin{array}{c}\text { OIL- } \\
\text { SB1070 }\end{array}$ & 2010 & Street/Jail & $\begin{array}{c}\text { Identification } \\
\text { noncitizen }\end{array}$ & $\begin{array}{c}\text { State and } \\
\text { local law } \\
\text { enforcement } \\
\text { entities }\end{array}$ & State & State governor & \\
\hline $\begin{array}{l}\text { Employment- } \\
\text { Base Measures }\end{array}$ & $\begin{array}{c}\text { E- } \\
\text { Verify }\end{array}$ & 2006- & Firms & $\begin{array}{l}\text { Deter the } \\
\text { hiring of } \\
\text { unauthorized } \\
\text { immigrants. }\end{array}$ & Employer & State & State governor & \\
\hline
\end{tabular}

Note: Sources: National Conference of State Legislatures (NCSL) and U.S. Immigration and Customs Enforcement (ICE) 


\section{Appendix B}

\section{Table B.1.1: Definition of Key Variables}

Poverty 100

Poverty 150

Log (Real Household Income)

Single Headed Household

HH Head w/HS +

HH Head Does not Speak English

Years in the U.S. of the HH Head

Age of the HH Head

No. of Kids in the $\mathrm{HH}$

Unemployment Rate in CONSPUMA

Share of Likely Unauthorized in CONSPUMA

Share of Low-skilled in Agriculture in the 80s
Dummy variable

1-Household income is below the poverty threshold 0-Otherwise

Poverty threshold: Established by the Social Security Administration in 1964, and subsequently modified by Federal interagency committees in 1969 and 1980.

Dummy variable

1-Household income is less than 1.5 times the poverty threshold

0-Otherwise

Household income is the total pre-tax money income earned by all members in the family from all sources for the previous year.

Dummy variable 1-Single headed family

0-Two-parent family

Educational attainment of the head of the family 1-Head of the household with more than HS diploma 0-Otherwise

English proficiency of the household head 1-Household head does not speak English or does not speak it well

0-Otherwise

Number of years of U.S. residency of the household head

Age of household head

Number of children ages 0 to 18 residing in the household

Unemployment rate by CONSPUMA and year

Percentage of Hispanic no-citizen population by CONSPUMA and year

Share of non college-educated with at most a high school diploma working in the Agriculture sector in the 80 s by CONSPUMA 
Appendix B

Table B.1.2: Definition of Key Variables

\begin{tabular}{|c|c|}
\hline Share of Low-skilled in Manufacturing in the 80s & $\begin{array}{l}\text { Share of non-college educated with at most a high school } \\
\text { diploma working in the Manufacturing sector in the } 80 \text { s } \\
\text { by CONSPUMA }\end{array}$ \\
\hline Share of Low-skilled in Construction in the 80s & $\begin{array}{l}\text { Share of non-college educated with at most a high school } \\
\text { diploma working in the Construction sector in the } 80 \text { s by } \\
\text { CONSPUMA }\end{array}$ \\
\hline Share Voting Republican & $\begin{array}{l}\text { Share of votes going to Republican candidates for the } \\
\text { U.S. House of Representatives by state and year. Source: } \\
\text { Office of the Clerk, US House of Representatives, } \\
\text { http://clerk. } \\
\text { house.gov/member_info/electionInfo/index.aspx. Values } \\
\text { between election dates are calculated by linear } \\
\text { interpolation. }\end{array}$ \\
\hline
\end{tabular}

Note: All the variables are constructed using ACS data from 2005 to 2011. 


\section{Appendix C}

Table C.1: Descriptive Statistics for Living in Poverty for Alternatives Samples

\begin{tabular}{lccccc}
\hline Samples: & Mean & S.D. & Min & Max & Observations \\
\hline More than 5 year of U.S. Residency & 0.30 & 0.46 & 0.00 & 1.00 & 118,529 \\
HH no HS diploma & 0.38 & 0.49 & 0.00 & 1.00 & 75,091 \\
HH Head is not older than 45 years old & 0.32 & 0.47 & 0.00 & 1.00 & 130,275 \\
\hline
\end{tabular}

